PIOTR KULESZA* - LUBLIN

MAGDALENA LUBIARZ** - LUBLIN

MAŁGORZATA ŻAK-KULESZA*** - LUBLIN

\title{
KULTUROWE, HISTORYCZNE I RELIGIJNE ZNACZENIE KAPLICZEK I KRZYŻY PRZYDROŻNYCH W GMINIE TRZYDNIK DUŻY
}

Tematyce kapliczek i krzyży przydrożnych, nazywanych „małą architekturą sakralną" od lat poświęcane są monografie, opracowania zbiorowe, sesje naukowe, wydawnictwa albumowe i popularnonaukowe ${ }^{1}$. Od szeregu lat prowadzone są badania terenowe, skupiające się na zagadnieniach etnograficznych, kulturoznawczych, folklorystycznych, antropologicznych, jak i językoznawczych. Zajmowano się także inwentaryzacją i opisem architektonicznej typologii kapliczek i krzyży. Natomiast historyczny i artystyczny aspekt podejmowanych badań dotyczy kwestii patronatu, ikonografii obrazów i figur oraz wizerunków kultowych ${ }^{2}$. Odrębna tematyka badań skupia się na formach praktyk religijnych, społecznym zna-

* Piotr Kulesza - dr historii sztuki; inż. arch. krajobrazu; adiunkt w Instytucie Architektury KUL; e-mail: pkulesza@kul.pl

** Magdalena Lubiarz - dr hab. nauk rolniczych; adiunkt w Instytucie Architektury Krajobrazu KUL; e-mail: lubiarz@kul.pl

*** Małgorzata Żak-Kulesza - dr historii sztuki; asystent w Instytucie Kulturoznawstwa KUL; e-mail: malzak@kul.lublin.pl

' J. Petera, Kapliczki drewniane na Lubelszczyźnie, „Z zagadnień kultury ludowej”, 2-3 (1981), s. 63-106; P. Kondraciuk, A. Urbański, Kapliczki, figury i krzyże przydroże w pejzażu pogranicza, Lublin-Zamość 2008; A. Bujak, Krzyż polski, Krajobraz i sacrum, t. 3, Kraków 2011; S. Kobojek, Polskie Kapliczki, Warszawa 2008.

${ }^{2}$ E. Ilcewicz, Święta Otylia patronka Urzędowa, Urzędów 1999, s. 11-12. M. Tymochowicz, Patroni kapliczek przydrożnych z obszaru Lubelszczyzny, w: „Prace Komisji Krajobrazu Kulturowego" nr 21, Obiekty religijne w krajobrazie, Sosnowiec 2013, s. 141-150; A. Szykuła, Kapliczki i figury przydrożne św. Jana Nepomucena na terenie gminy Labunie, „Zamojski Tygodnik Kulturalny”, 1-2 (2006) s. 62-68; Publikacje D. Powiłańskiej-Mazur dotyczące patronatu Św. Mikołaja i św. Jana Nepomucena: Patron powodzian, tonących, spowiedników, mostów: o rzeźbach św. Jana Nepomucena w regionie lubelskim, „Twórczość Ludowa” (dalej: TL), 19(2004) nr 4 s. 16-18; taż, Kapliczki św. Mikołaja na Lubelszczyźnie, TL, 20 (2005) nr 1-4, s. 65-67; A. Szykuła, Obiekty sa- 
czeniu tego typu obiektów w tradycji religijnej i we współczesnych zwyczajach wybranych społeczności lokalnych ${ }^{3}$. Również przyrodnicy i architekci krajobrazu kierują swoje zainteresowania badawcze ku przydrożnym obiektom sakralnym. Inwentaryzują i analizują kompozycje przyrodnicze związane z tymi obiektami, jak i przemiany w doborze i charakterze zieleni otaczającej małą architekturę sakralną ${ }^{4}$. Powstające opracowania w przeważającej mierze dotyczą niewielkiego obszaru geograficznego, jakim jest jednostka administracji państwowej (gmina, miasto) lub kościelnej (dekanat, parafia). W województwie lubelskim znacząca liczba publikacji dotyczy kapliczek i krzyży z obszaru ziemi janowskiej i biłgorajskiej $^{5}$ oraz północno-wschodniej i wschodniej części województwa, okolic Radzynia Podlaskiego, Lukowa, Lubartowa, Chełma, Zamościa, ale także samego Lublina oraz okolicznych miejscowości i gmin jak: Urzędów, Kraśnik, Mełgiew ${ }^{6}$.

kralne i figury św. Jana Nepomucena w krajobrazie gminy Zamość, „Zamojski Kwartalnik Kulturalny", 2008, nr 3(96), s. 18-21.

${ }^{3}$ A. Gaweł, Przydrożne krzyże i kapliczki na Sokólszczyźnie jako dawne i wspótczesne ,akty wiary" ludu wiejskiego, w: Krzyże i kapliczki przydrożne jako znaki spolecznej, kulturowej i religijnej pamięci, red. J. Adamowski, M. Wójcicka, Lublin 2011, s. 229-243; K. Czerwińska, Dawne $i$ wspótczesne role małej architektury sakralnej w społecznościach lokalnych (na przykładzie Śląska Górnego i Cieszyńskiego), w: Krzyże i kapliczki przydrożne jako znaki społecznej, kulturowej i religijnej pamięci, red. J. Adamowski, M. Wójcicka, Lublin 2011, s. 141-153.

${ }^{4}$ P. Kulesza, M. Lubiarz, Przydrożne obiekty sakralne w gminie Metgiew (woj. lubelskie) analiza kulturowo-krajobrazowa, w: Obiekty religijne w krajobrazie, Sosnowiec 2013, s. 127-140.

${ }^{5}$ Z.Ł. Baranowski, Figury, krzyże i kapliczki przydrożne w powiecie janowskim, „Janowskie Korzenie. Pismo regionalne ziemi janowskiej”, 9 (2007) s. 61-91; J. Łukasiewicz, Drogowskazy wiary. Krzyże i kapliczki ziemi janowskiej, Zamość 2011; K. Garbacz, Na szlaku biłgorajskich kapliczek i krzyży przydrożnych, Zielona Góra 2009 - Bardzo szczegółowe i pod względem historycznym wnikliwe opracowanie podjętego tematu. Autor przeprowadził szczegółową kwerendę źródłową przywołując najstarsze wzmianki o opisywanych obiektach, relacje świadków, dawne opowieści i podania, współczesną sytuację i sposób funkcjonowania kapliczek i krzyży w praktykach religijnych, sposoby odnawiania i dbałość społeczności lokalnej o te obiekty.

M. Pękalski, Drewniane kapliczki nagrobne w powiecie bilgorajskim, „Polska Sztuka Ludowa” (dalej: PSL), 15 (1961) br 2, s. 94-96; D. Powiłańska, Kapliczki i krzyże przydrożne w Biłgorajskim $w$ fotografii Piotra Maciuka, „Studia i Materiały Lubelskie”, 14 (1997) s. 157-162.

${ }^{6}$ A. Gauda, Ludowe krzyże żelazne na Lubelszczyźnie, „Studia i Materiały Lubelskie”, 12 (1987) s. 109-144. Publikacja nie uwzględnia krzyży z obszaru gminy Trzydnik, ani nawet z powiatu kraśnickiego. Najbliższe gminie Trzydnik Duży miejscowości, w których przeprowadzono inwentaryzację to: Antoniówka i Potok Stary należące do ziemi janowskiej.

A. Ławicka, Krzyże drewniane z insygniami Męki Pańskiej na Lubelszczyźnie, TL, 4 (2000) s. 7-10; J. Kucharzak, Krzyże i kapliczki Łukowa i okolic jako świadkowie lokalnych wydarzeń, w: Krzyże i kapliczki przydrożne jako znaki spotecznej, kulturowej, s. 309-319; S. Skibiński, Kapliczki $i$ światki powiatu chetmskiego w świetle źródet archiwalnych, PSL, 4 (1967), s. 223-241; J. PeteraGórak, Kapliczki i krzyże przydrożne, w: Dziedzictwo kulturowe Lubelszczyzny. Kultura Ludowa, red. A. Gauda, Lublin 2001, s. 21-28. Bibliografia na temat kapliczek i krzyży z okolic Urzędowa, Łęcznej, z powiatu biłgorajskiego i z okolic Lublina.

G. Żurawicka, Kapliczki w krajobrazie, „Zamojski Tygodnik Kulturalny”, nr 3 (1995), s. 9-11; M. Pękalski, Kapliczki i krzyże w Urzędowie, „Z bliska i z daleka”, 6 (57), 1938, nr 9; Z. Lipski, Kapliczki i krzyże przydrożne w parafii Dąbrowica, Lublin 2000; J. Jodłowska, Kapliczki i krzyże w 
Gminy i działające w nich towarzystwa regionalne oraz ośrodki kultury i biblioteki podejmują starania, by dokonywać inwentaryzacji i historycznego opisu znajdujących się na ich terenie zabytków małej architektury sakralnej. Jednak Gmina Trzydnik Duży nie doczekała się dotychczas żadnej kompleksowej inwentaryzacji tej grupy obiektów. Również Katalog zabytków sztuki w Polsce nie wymienia obiektów małej architektury sakralnej znajdujących się na tym terenie.

Lokacje miejscowości należących współcześnie do gminy Trzydnik Duży sięgają czasów średniowiecza. Najstarsze wzmianki o miejscowościach pochodzą już z XIV wieku i dotyczą wsi Rzeczyca Księża (XIV w.), Rzeczyca Ziemiańska (XV w.), Węglin (XV w.), Łychów (XV w.), Trzydnik (XV w.), Olbięcin (XVI w.) ${ }^{7}$. Gmina położona jest na przebiegu starych traktów z Lublina do Sandomierza, z Kraśnika do Janowa Lubelskiego i Zamościa oraz Lwowa ${ }^{8}$. W gminie Trzydnik Duży znajdują się ważne historycznie i kulturowo kościoły drewniane: w Rzeczycy Księżej z XVII wieku i w Rzeczycy Ziemiańskiej poświęcona w 1753 roku, będące najstarszymi parafiami należącymi obecnie do gminy ${ }^{9}$.

Gmina Trzydnik Duży posiada znaczący zasób zabytkowy, na który składają się budowle należące do dawnych założeń dworskich, pałac dworski rodziny Rudlickich w Olbięcinie (rządcówka, czworaki, wołownia, stajnie), drewniane budownictwo wiejskie (domy, spichlerze, kuźnie), zabytkowe budynki szkolne,

gminie Jastków jako „,świadkowie zdarzeń”, w: Krzyże i kapliczki przydrożne jako znaki społecznej, kulturowej, s. 295-300; Kapliczki i krzyże przydrożne w gminie Michów (folder promocyjny), red. Janina i Marian Wicha, Towarzystwo Przyjaciół Michowa, 2015.

Piękno kapliczek, figur i krzyży przydrożnych - gmina Puławy, oprac. i red. M. Pasik, Góra Puławska 2014; Z. Życzyńska-Bajek, M. Bajek, Peretki architektury. Kapliczki okolic Stalowej Woli, Wydawnictwo Sztafeta, Stalowa Wola 2005; Zabytkowe kapliczki w gminie Urzędów, Urzędów 2014; Kapliczki i krzyże przydrożne w pejzażu Ziemi Garbowskiej, red. R. Bartnik, M. Wylaź, Z. Małyszek, Lublin 2014; W. Krasucki, Krzyże i kapliczki przydrożne jako znaki podziatu przestrzeni, PSL, 40 (1986) nr 3-4, s. 225-232.

${ }^{7}$ Stownik Geograficzny Królestwa Polskiego i innych krajów stowiańskich, Warszawa, T. VII 1886, T. X 1889, T. XII 1892, T. XIII 1893, Rzeczyca Ziemiańska T. X, s. 132-133; Rzeczyca Księża T. X, s. 133; Węglin T. XIII, s. 253; Trzydnik T. XII, s. 580-581; Olbięcin T. VII, s. 445.

W. Ćwik, J. Reder, Lubelszczyzna. Dzieje rozwoju terytorialnego, podziałów administracyjnych i ustroju wtadz, Lublin 1977.

Ziemia kraśnicka w latach 1474-1795 administracyjnie należała do powiatu urzędowskiego. Po raz pierwszy powiat kraśnicki uzyskał samodzielność w 1810 roku, ale jego status administracyjny przetrwał tylko do 1813 roku. Następnie ziemia kraśnicka należała do okręgu janowskiego (od 1845). Powiat janowski od 1867 roku obejmował również gminę Trzydnik. Ziemie te podlegały guberni lubelskiej. W. Szymanek, Z dziejów powiatu janowskiego i kraśnickiego, s. 16-42.

${ }^{8}$ J. Reder, Powiat kraśnicki (rys historyczny), w: Z dziejów powiatu kraśnickiegp. Materiaty z sesji, red. K. Myśliński, R. Szaflik, Lublin 1964, s. 186-190.

${ }^{9}$ Większość sołectw w gminie Trzydnik Duży według podziału kościelnego przynależy do diecezji sandomierskiej. Natomiast wśród 20 sołectw gminy trzy miejscowości przynależą do innego obszaru w ramach administracji kościelnej i państwowej, są to Rzeczyca Księża, należąca do archidiecezji lubelskiej oraz miejscowości Budki i Agatówka, podległe gminie Trzydnik Duży, ale wchodzące w skład parafii Gościeradów w gminie Gościeradów, przypisane diecezji sandomierskiej. Monografia dotycząca jednej z parafia zob.: B. Suchora, Dzieje Parafii Przemienienia Pańskiego w Rzeczycy Ziemiańskiej w latach 1945-1992, Lublin 1998, praca mgr, msp KUL. 
budynek ochronki oraz obiekty związane z działalnością gospodarczo-przemysłową: stare młyny i gorzelnia. Wartość zabytkową gminy tworzą również stare nekropolie w Rzeczycy Księżej, Rzeczycy Ziemiańskiej i Olbięcinie oraz cmentarze wojenne w Węglinku, Łychowie i Budkach. Krajobraz kulturowy dopełniają liczne kapliczki domkowe i krzyże przydrożne oraz krzyże mogiłowe.

W lipcu i sierpniu 2015 roku na terenie gminy Trzydnik Duży wykonano badania terenowe dotyczące sakralnych obiektów przydrożnych. Podczas analiz zapisano obserwacje odnośnie stanu inwentaryzowanych obiektów, znajdujących się na nich inskrypcji i inne istotne informacje. Wykonano także dokumentację fotograficzną zarówno samych obiektów sakralnych, jak i ich najbliższego otoczenia. Ponadto przeprowadzono wywiady z napotkanymi osobami, odnośnie historii badanych obiektów.

Zinwentaryzowano 73 przydrożne obiekty sakralne, wśród których 17 stanowią kapliczki domkowe i szafkowe. Pozostałe to krzyże drewniane oraz metalowe i dwie figury: rzeźba Matki Bożej Fatimskiej w grocie oraz Matka Boża Niepokalanie Poczęta na kapliczce słupowej w Rzeczycy Księżej (1907). Wśród zinwentaryzowanych obiektów sakralnych występują kapliczki domkowe (fot. 1, 2, 3, 12), skrzynkowe, szafkowe kapliczki nadrzewne (fot. 4), kapliczka słupowa (Olbięcindwór), kamienne krzyże postumentowe (fot. 5) oraz krzyże drewniane i metalowe. Patronat kapliczek koncentruje się na osobie Matki Bożej, w kilku przypadkach centralnym wizerunkiem jest przedstawienie rzeźbiarskie lub obrazowe Jezusa. Pojedynczym obiektom przypisany został patronat św. Jana Nepomucena (fot. 6) i św. Floriana (fot. 7). Wśród wszystkich zinwentaryzowanych obiektów 10 stanowi prywatną fundację osób lub rodzin: 3 kapliczki, 1 figura i 6 krzyży.

Historii ziemi kraśnickiej i janowskiej, do jakich przynależy gmina Trzydnik Duży, swoje liczne prace poświęcił historyk i regionalista Wit Szymanek oraz wielu regionalistów związanych z Kraśnickim Towarzystwem Regionalnym ${ }^{10}$. Kronikarzem życia religijnego gminy, a w szczególności parafii Rzeczyca Ziemiańska, jak i drobiazgowym dokumentalistą minionych wydarzeń był ks. kanonik Aleksander Baca, autor opracowania, w którym uwiecznił istotne fakty z przeszłości wszystkich miejscowości należących pierwotnie do tej najstarszej parafii, a tym samym niemal całej gminy ${ }^{11}$. W publikacji ks. A. Bacy, który odwoływał się do źródeł archiwalnych i kronik parafialnych, znalazły miejsce również ustne opowieści i relacje mieszkańców, które nigdy wcześniej nie zostały utrwalone, a wyjaśniają wiele historycznych zdarzeń i faktów. Jednak dotychczas nie została przeprowadzona kompleksowa inwentaryzacja obiektów sakralnych w gminie Trzydnik Duży, nie został zbadany ich walor historyczno-kulturowy ani

${ }^{10}$ W. Szymanek, Z dziejów powiatu janowskiego i kraśnickiego w latach 1474-1975, Lublin 2003. KTR zostało założone w 1962 roku z inicjatywy Jana Stelmaszczyka, Feliksa Kopcia i wielu lokalnych animatorów życia kulturalnego, nauczycieli i pasjonatów historii. O historii gminnych miejscowości pisał Janusz Kuryłło.

${ }^{11}$ A. Baca, Historia i teraźniejszość. Parafia Rzymsko-katolicka pw. Przemienienia Pańskiego w Rzeczycy Ziemiańskiej, Sandomierz 2007. 
też przyrodniczy ${ }^{12}$. Dlatego przeprowadzone badania miały na celu przywołanie i utrwalenie wartości historycznej, jaką reprezentują obiekty sakralne, ich forma estetyczna, architektoniczna, kulturowa oraz znaczenie kultowe i pobożnościowe. Zwrócono również uwagę na otoczenie przyrodnicze towarzyszące omawianym obiektom, które na przestrzeni ostatnich kilku lat ulega ciągłym przekształceniom, ale też i trwałej destrukcji. Przestrzeń krajobrazowa, jak też kulturowa, w której zakorzenione są małe obiekty sakralne, powiązana jest $\mathrm{z}$ historią lokalną i dziejami społeczności zamieszkującej teren gminy. Historia poszczególnych obiektów, geneza ich powstania, wydarzenia okolicznościowe i obrzędy religijne z nimi związane tworzą spójny obraz tradycji kulturowej gminy i jej mieszkańców.

\section{Geneza wznoszenia kapliczek}

Geneza wznoszenia kapliczek i krzyży, szczególnie tych prywatnych, związana jest zwykle $\mathrm{z}$ wydarzeniami mającymi przełomowe i doniosłe znaczenie $\mathrm{w}$ życiu osobistym fundatorów. Budowa kapliczek lub krzyży upamiętniać może cudowne ocalenie lub też tragiczne zdarzenia, jest formą dziękczynienia lub też prośbą o Bożą opiekę i wstawiennictwo. Wznoszono je w celu ochrony wsi przed różnorako rozumianym złem, przed klęskami żywiołowymi, niedostatkiem, ale też i wojną, z prośbą społeczności o zapewnienie błogosławieństw mieszkańcom, w celu ochrony zdrowia. Ich budowa była wyrazem podziękowania za ocalenie i powrót z niewoli, za dar potomstwa, przywrócenie zdrowia. Ponadto tego typu fundacjami uwieczniano również dramatyczne zdarzenia, jak śmierć, tragiczne zdarzenia, pożogi, represje wojenne, wypadki losowe, które dotykały lokalną społeczność. Krzyże i kapliczki są także znakami wiary w trudnych czasach, utrwalają w lokalnej pamięci wydarzenia historyczne, np. „ukaz tolerancyjny” z 1905-1907, rocznice odzyskania niepodległości, zakończenie wojny, lokację miejscowości. Odrębną kategorię stanowią wydarzenia o charakterze historyczno-religijnym, jak wybór kard. Karola Wojtyły na papieża Jana Pawła II i rocznice pontyfikatu, papieskie pielgrzymki, peregrynacje obrazu świętego, a nawet cudowne objawienia. Wznoszenie krzyży oraz kapliczek wynika z najbardziej podstawowej dla niewielkiej społeczności potrzeby wyrażenia własnej pobożności, jak też jest znakiem więzi i utożsamienia się ludzi z miejscem zamieszkania ${ }^{13}$. Od wieków wokół tych obiektów tworzy się i umacnia lokalne poczucie wspólnoty. Dlatego małe obiekty sakralne zajmują tak szczególne miejsce w krajobrazie małych miasteczek, wsi, gmin oraz w krajobrazie polskich pól, dróg, czy leśnych uroczysk.

O genezie powstania tego typu obiektów świadczą tabliczki lub historyczne napisy umieszczane na ramionach krzyży, na tabliczkach i postumentach. Na zinwentaryzowanych obiektach gminy Trzydnik treść inskrypcji bywa bardzo la-

${ }^{12}$ Historii, zabytkom i wybitnym mieszkańcom gminy Trzydnik Duży został poświęcony jeden z numerów pisma „Regionalista. Czasopismo Kraśnickiego Towarzystwa Regionalnego”, 17 (2001). Studia źródłowe, historyczne omówienie dawnych dziejów powiatu kraśnickiego zob. Z dziejów powiatu kraśnickiego. Materiaty z sesji naukowej, red. K. Myśliński, R. Szaflik, Lublin 1963; Archiwum Państwowe w Lublinie Oddział w Kraśniku, Akta miasta Kraśnika.

${ }^{13}$ Zob. teksty w: Krzyże i kapliczki przydrożne jako znaki społecznej, kulturowej i religijnej pamięci, red. J. Adamowski, M. Wójcicka, Lublin 2011. 
koniczna, są to tylko daty lub krótkie wezwanie do Boga, ale występują także dłuższe wierszowane formuły, będące wyrazem ludowej pobożności. Pod względem historycznym cennymi informacjami, jakie widnieją na krzyżach oraz kapliczkach, są uwiecznione nazwiska i imiona fundatorów oraz daty fundacji. $\mathrm{Na}$ obiektach umieszczono następujące lata: 1905, 1907, 1910, 1918, 1945, 1946, 1948, 1951, 1958, 1981, 2009.

\section{Kapliczki historyczne}

Pod względem historyczno-kulturowym cennym zasobem gminy Trzydnik Duży są dwie kapliczki domkowe datowane na połowę XIX wieku i jedna z jego końca. Te najstarsze i zarazem najcenniejsze obiekty znajdują się w Łychowie Gościeradowskim (kapliczka z 1847 roku, ufundowana przez małżeństwo Wójcików fot.1) oraz w Łychowie Szlacheckim (kapliczka z 1856 roku, ufundowana przez Wojciecha i Wiktorię Pytlak, fot. 12). Trzecia z nich to neogotycka kapliczka rodziny Gładkowskich zlokalizowana w Rzeczycy Ziemiańskiej (fot. 3). Zarówno te obiekty małej architektury sakralnej, jak i kilka innych posiada wartościowe wyposażenie w postaci rzeźbionych figur lub obrazów, głównie oleodruków podkolorowanych.

Analizując wartość estetyczną, jak też historyczną wyposażenia kapliczek na terenie gminy Trzydnik Duży wśród zgromadzonych przedmiotów kultu wyróżniają się rzeźbione figury: św. Floriana w kapliczce w Rzeczycy Ziemiańskiej (fot. 7) i Liśniku Małym (fot. 6), drewniana rzeźba Jana Nepomucena w kapliczce Pytlaków. Ponadto niewielka rzeźba Matki Bożej w kapliczce Gładkowskich oraz kamienna figurka Maryi umieszczona na zewnątrz, w niszy szczytu tejże kapliczki. Wyjątkowym obiektem jest rzeźba Chrystusa prowadzonego na Mękę z kapliczki domkowej w Owczarni (fot. 8). Przykładem historycznej snycerki jest także drewniana figura Jana Nepomucena w kapliczce w Liśniku Małym (fot. 6) oraz niewielkie drewniane rzeźbione figury Maryi i krucyfiks w kapliczce szafkowej w Owczarni (fot. 4). Do cennego wyposażenia kapliczek zaliczyć należy uznawany za cudowny obraz Matki Bożej Częstochowskiej oraz polichromie dekorujące kapliczkę Wójcików w Łychowie Gościeradowskim (fot. 9, 10).

Wyjątkowym pod względem architektonicznym obiektem jest neogotycka, ceglana kapliczka w Rzeczycy Ziemiańskiej, datowana na koniec XIX wieku. Jej powstanie związane jest z prywatną inicjatywą rodziny Gładkowskich (fot. 3). Kapliczka leży na posesji darczyńców, a zgodę na jej wzniesienie udzielił ówczesny proboszcz. Członkowie rodziny nie znają prawdziwych powodów wybudowania kapliczki, wzmiankują o wydarzeniach powstańczych, jednak nie podają żadnych dokładniejszych danych ${ }^{14}$. W literaturze oraz w relacji członków rodziny fundatorów, wymieniane jest imię Marii Gładkowskiej, żony tamtejszego młynarza, jako inicjatorki wzniesienia kapliczki ${ }^{15}$. Wyjątkowo prezentuje się architektoniczna struktura kapliczki, sugestywnie przywołująca cechy neogotyckiej budowli,

${ }^{14}$ Relacja ustna uzyskana podczas badań terenowych przeprowadzonych w 2015 r. przez autorów publikacji. Informację tę przekazał jeden z członków rodziny fundatorów.

${ }^{15}$ Baca, Historia i teraźniejszość, s. 142. 
z ostrołukowym fryzem arkadkowym pod gzymsem, szkarpami wchodzącymi w mur, ostrołukowymi profilami okien i drzwi oraz schodkowym szczytem, w którego arkadkowej niszy ustawiono niewielką figurkę Madonny Różańcowej. Centralnym obiektem wyposażenia kapliczki jest obraz olejny z wizerunkiem Matki Bożej Częstochowskiej namalowany przez B. Dutkowską w latach 50. XX wieku. Wiadomym jest, że autorka mieszkająca w Kozienicach, pochodziła z rodziny fundatorów kapliczki. Była siostrą ojca Piotra Gładkowskiego, który przekazał nam tę relację. We wnętrzu kapliczki znajduje się rokokowa konsola pełniąca funkcję ołtarzyka, na którym ustawiono obraz i zabytkową figurkę Immaculaty. Mebel najprawdopodobniej pochodzi z wyposażenia kościoła, gdzie pierwotnie był częścią ołtarza bocznego (fot. 11). Kapliczka znajduje się na prywatnej posesji, na niewielkiej skarpie, na tle zieleni świerków i niskich krzewów. Wokół widoczne są ślady po usuniętych drzewach, które kiedyś stanowiły przyrodnicze otoczenie obiektu. Kapliczka jest odseparowana od ulicy dużym trawnikiem, a ponadto wysokim betonowym płotem. Taka lokalizacja budowli oraz prywatny charakter miejsca ograniczają prowadzenie w jej obrębie praktyk dewocyjnych przez lokalną społeczność. Ponadto funkcje te przejęła znajdująca się w pobliżu kapliczka św. Floriana z 1946 roku.

Historycznym obiektem jest również kapliczka domkowa w Owczarni, w której znajduje się cenna drewniana figura Chrystusa prowadzonego na Mękę (fot. 8). Rzeźba wyróżnia się wyjątkowym stylem, zdradza wprawną rękę twórcy, szczególnie w sposobie odtworzenia układu draperii, ale też w szlachetności rysów twarzy Jezusa i subtelności kolorystycznej polichromii. Figura jest unikatowym w skali gminy przykładem tematu kapliczkowej rzeźby kultowej. Architektoniczna struktura kapliczki wspaniale komponuje się z przyrodniczą oprawą, którą tworzą dwa okazałe kasztanowce. Lokalizacja kapliczki wyznacza punkt przebiegu dawnego szlaku, drogi prowadzącej z Kraśnika i okolicznych miejscowości do kościoła w Rzeczycy Księżej i Ziemiańskiej.

Historyczny charakter posiadają także kapliczki domkowe w: Rzeczycy Księżej z 1906 roku z pięknym tłoczonym i podkolorowanym złotą farbą oleodrukiem z wizerunkiem Matki Bożej Częstochowskiej, kapliczka w Dąbrowie Olbięckiej z 1918 roku oraz kapliczka w Kolonii Trzydnik poświęcona Chrystusowi z 1958 roku.

\section{Wspomnienia i relacje świadków związane z historią kapliczek i krzyży}

Mała architektura sakralna posiada utrwalone miejsce w krajobrazie miejscowości i z nimi lokalna społeczność wiąże istotne wydarzenia historyczne, a nawet przekazy legendarne czy opisy cudownych zdarzeń, jak z kapliczką Wójcików w Łychowie Gościeradowskim czy z figurą św. Floriana w Rzeczycy Ziemiańskiej. $Z$ wieloma obiektami wiążą się opowieści wyjaśniające powody i realia ich powstawania. Cennym wynikiem kwerendy i wywiadu społecznego jest fakt, że historie te nigdy wcześniej nie zostały spisane i pozostawały nieznane ogółowi społeczności lokalnej.

Najstarszą kapliczką na terenie gminy Trzydnik Duży jest kapliczka fundacji małżeństwa Wójcików w Łychowie Gościeradowskim z 1847 roku (fot. 1). Wnętrze zdobią polichromie o bardzo ciekawym i znaczącym zestawie postaci 
i dekoracjach. Wśród malarskich motywów rozpoznać można postać Maryi Niepokalanej, prawdopodobnie św. Stanisława w stroju biskupim z pastorałem, św. Andrzeja Apostoła, św. Sebastiana przeszytego strzałami i św. Rocha w stroju podróżnym, niosącego tobołek, który odsłania ranę na udzie, i któremu towarzyszy pies. Grupę świętych dopełniają dwie postaci kobiece: jedna w wianku kwietnym na głowie, prawdopodobnie św. Dorota, druga z palmą męczeństwa (fot. 9, 10). Wybór dwojga świętych związany jest z osobami fundatorów, ponieważ św. Andrzej i św. Dorota to imienni orędownicy małżonków Wójcickich. Nad wejściem do kapliczki na osi drzwi wymalowano litery alfa $(A)$ i omega $(\Omega)$ oraz monogram chryzmon, zaś po obu stronach dwie prostokątne tablice z inskrypcją dedykacyjną potomków fundatorów i informacją o konserwacji malowideł w 1957 roku. NIECH KRÓLUJE NAM PANI NASZA/ MATKA BO[SKA CZESTOCHOWSKA ŁYCHOWSKA]/ A BOGU W TROJCY JEDYNEMU/ NIECH BĘD[ZIE CZEŚĆ] I CHWAŁA NA WIEKI / WALER[IA] [...] RESZTAK. W drugim polu większość tekstu już nieczytelna: [...]ÓW POD [...] / STEFANA SZYMAŃSKIEGO/ 1957. Ponadto wzdłuż górnej krawędzi ściany pierwotnie biegł fryz z motywem floralnym, a także napis UWIELBIAJ DUSZO MOJA PANA. Obecnie oba te elementy są już niemal zupełnie zatarte i prawie nieczytelne. Motywem zdobniczym dobrze widocznym jest wazon wypełniony kwiatami i owocami. Kapliczka jest najcenniejszym artystycznie, ale także niezwykle ważnym ze względów religijnych obiektem sakralnym w gminie Trzydnik Duży.

Z miejscem tym i znajdującym się w niej obrazem Matki Bożej Częstochowskiej związane jest podanie o cudownym zdarzeniu. Historię i relacje świadków opisała Józefa Pytlak, która udostępniła podczas kwerendy swój rękopis ${ }^{16}$. Według podań mieszkańców we wczesnych latach 50 . XX wieku, w miesiącu maju, we wnętrzu kapliczki pojawił się cudowne światło, które następnie przemieściło się nad łąki otaczające kapliczkę. Świadkami tego zdarzenia były trzy dziewczynki modlące się wówczas w kapliczce, które podążyły za blaskiem. Dzieci zauważyły, że łuna odbijając się na tafli wody pobliskiej rzeki Karasiówce, stworzyła wizerunek twarzy Matki Bożej. Wiadomość o tym zdarzeniu dotarła do lokalnej społeczności i wywołała bardzo gorliwe akty pobożności. Ludzie tłumnie przychodzili do kapliczki i adorowali znajdujący się w niej obraz Jasnogórskiej Pani. Według podań, w wyniku tego objawienia, obraz z wizerunkiem Maryi zyskał nowy, niejako w cudowny sposób odnowiony blask. Obraz z wizerunkiem Hodegetrii, w drewnianej, złoconej i rzeźbionej sukience do dziś znajduje się w kapliczce i jest najcenniejszym obiektem kultowym, często określanym jako „cudowny”. Według relacji mieszkańców obraz został przyniesiony z Częstochowy jeszcze przed II wojną światową Mieszkańcy wystosowali prośbę do córek założycieli kapliczki, by wsparły inicjatywę odnowienia obiektu. Jedna z nich, Waleria Opoka, mieszkająca w USA, odwiedziła Łychów Gościeradowski i zleciła rozpoczęcie prac remontowych. W 1957 i 1958 roku działania te podjęli mieszkańcy wsi: Stefan Szymański, malarz Pulikowski, Konstanty Szot i murarz Słowak.

${ }^{16}$ Autorzy pragną złożyć serdeczne podziękowanie p. Józefie Pytlak, nauczycielce ze szkoły w Łychowie Gościeradowskim, za życzliwe spotkanie i możliwość wglądu do rękopisu opisującego te historyczne zdarzenia. 
W relacji J. Pytlak prace prowadzono w oparciu o dokumentację konserwatorską, tj. zdjęciową i za zgodą władz konserwatora zabytków ${ }^{17}$. Nad wejściem do kapliczki umieszczono tablicę $\mathrm{z}$ dedykacją fundacji: TE KAPLICE ZBUDOWALI NA CZEŚĆ MATCE/ BOSKIEJ CZĘSTOCHOWSKIEJ/ BOGU W TRUJCY (sic!) SWIETEJ JEDYNEMU/ ANDRZEJ I DOROTA WÓJCIKI/ 1847 ROK ${ }^{18}$. Obecnie, po sześćdziesięciu latach od tych działań, lokalna społeczność prowadzi starania o zebranie funduszy na przeprowadzenie prac konserwatorskich. Niestety w 1995 roku dokonano interwencji w obrębie obiektu, ponieważ ścięto wiekowe kasztanowce, jakie okalały budynek. Kapliczka, położona w malowniczej, przyrodniczej scenerii, wśród łąk i wijącej się rzeki, pozbawiona została swej cennej oprawy roślinnej.

Druga zabytkowa kapliczka w Łychowie Szlacheckim, datowana na 1856 rok pochodzi z fundacji rodziny Pytlaków. Zgromadzone w jej wnętrzu dewocjonalia, głównie oleodruki są świadectwem gorliwości religijnej mieszkańców. Natomiast w niszy, w szczycie kapliczki ustawiona została niewielka drewniana rzeźba św. Jana Nepomucena, która jest drugim wizerunkiem tego świętego w gminnych kapliczkach (fot. 12). Rzeźba jest lekko uszkodzona i odnowienia wymaga również jej polichromia, ale styl opracowania figury, układ draperii, lekkość i naturalność gestu postaci, pozwala zaliczyć rzeźbę do cennych przykładów snycerki ludowej.

Na podstawie relacji ustnych ustalono, że kapliczka w Dąbrowie Olbięckiej została zbudowana w latach 1916-1918 ${ }^{19}$, jako wotum dziękczynne za cudowne ocalenie i wyzwolenie $z$ obozu jenieckiego podczas I wojny światowej jednego z mieszkańców wsi - Kazimierza Szczepanika. Podczas odnowienia dachu nad kapliczką w 1989 umieszczono metalową tabliczkę z datą 1918. Ta data wydaje się być bardziej prawdopodobna, ponieważ wielu mieszkańców Dąbrowy brało czynny udział w działaniach I wojny światowej. Obecnie podjęto inicjatywę, aby odnowić kamienną figurkę Matki Bożej Niepokalanej, pochodzącą najprawdopodobniej z połowy XX wieku. Niestety przed kilkoma laty dokonano dewastacji przyrodniczego otoczenia kapliczki, gdyż wycięto dwie wiekowe lipy stojące u szczytu schodów wiodących do kapliczki. W efekcie z pierwotnego stanu sześciu drzew pozostały tylko dwa kasztanowce. Za kapliczką pojawiły się odrosty starych lip, które wycięto jeszcze w latach 60 . XX wieku.

Szczególna historia wiąże się z figurą św. Jana Nepomucena, którą do kapliczki w Liśniku Małym wyrzeźbił pielgrzym, wędrujący z Wołynia na Jasną Górę w latach 30. XX wieku (fot. 6). Właściciel posesji sąsiadującej z kapliczką wspominał, że materiał potrzebny do wykonania rzeźby czyli drewno lipowe, przekazany został przez jego babkę. Prace nad rzeźbą miały trwać 30 dni. Obecnie istniejąca ceglana kapliczka została wzniesiona w 1994 roku. W jej wnętrzu, na ołtarzu ustawiono rzeźbę świętego przedstawionego według tradycyjnej ikonografii w stroju kanonika: w sutannie, krótkiej pelerynie, komży i biretem na głowie.

${ }^{17}$ Małe ojczyzny Polaków. Łychów Gościeradowski. Eychów Szlachecki, opracowała Józefa Zofia Pytlak, rkp, s. 9-10. Opracowanie udostępnione dzięki uprzejmości p. Józefy Z. Pytlak.

${ }^{18}$ Zapis zgodny z oryginałem.

${ }^{19}$ Baca, Historia i teraźniejszość, s. 141 wymienia datę 1916. Natomiast na szczycie kapliczki znajduje się współczesna metalowa tabliczka z datą 1918. 
Święty pozbawiony jest swego naczelnego atrybutu, czyli krzyża, jednak układ rąk może sugerować jego pierwotne występowanie. Postać ujęta została w lekkim kontrapoście. Sposób wyrzeźbienia, odwzorowanie detali stroju, naturalne ułożenie fałd szat świadczą o biegłości warsztatowej artysty. Niestety współcześnie dokonano niewprawnej konserwacji, polichromując twarz świętego. W wyniku tych zabiegów rzeźba utraciła swój pierwotny artystyczny wyraz i wydaje się obiektem o niskiej klasie.

Przykładem osobistego zaangażowania mieszkańca w fundację kapliczki jest szafkowa kapliczka zawieszona na starej lipie we wsi Owczarnia (fot. 4). Podczas prowadzonej kwerendy jeden ze świadków przekazał, że została ona wykonana przez lokalnego stolarza o nazwisku Beksiak jeszcze na początku XX wieku. Cieśla przyniósł z Jasnej Góry figurę Maryi i Krucyfiks i dla nich wykonał tę szafkową nastawę.

O sile wiary w moc działania przydrożnych patronów świadczy znana wśród gminnej społeczności opowieść o św. Florianie z Rzeczycy Ziemiańskiej, który jeszcze przed żniwami „wymłócił zboża” okolicznym rolnikom (fot. 7). W 1963 roku nieznane osoby dokonały zbezczeszczenia figury świętego, wieszając na niej cepy. Krótko po tym zdarzeniu przez miejscowość przeszła potężna burza $\mathrm{z}$ trąbą powietrzną, która zniszczyła plony. Historię tę znają mieszkańcy nie tylko Rzeczycy, ale i całej gminy i postrzegają to zdarzenie jako rodzaj kary wymierzonej w społeczność, która nie oddała należnego szacunku świętemu. Kapliczkę zniszczono powtórnie w 1976 roku, ale od tego czasu nie odnotowano podobnych incydentów. Według relacji ks. Bacy rzeźba św. Floriana miała pierwotnie należeć do wyposażenia budynków dworskich w Trzydniku Dużym, z których po zniszczeniu dworu, została zabrana i umieszczona początkowo w dzwonnicy, a tuż po rozpoczęciu II wojny światowej, ustawiono ją na prywatnej posesji, za młynem Gładkowskich w Rzeczycy Ziemiańskiej. Istniejącą kapliczkę domkową wzniesiono w 1946 roku i do niej wstawiono rzeźbę ${ }^{20}$.

\section{Najstarsze gminne krzyże przydrożne - kapliczki słupowe}

Istotną wartość kulturowo-historyczną prezentują dwa krzyże kamienne w Łychowie Gościeradowskim, datowane na 1905, 1907 i 1910 rok. Są to krzyże kamienne zwane kapliczkami postumentowymi ${ }^{21}$, osadzone na stopniowanym cokole, tynkowane, bielone, dopełnione metalowym krucyfiksem lub krzyżem.

Podobne obiekty znajdują się także w Dąbrowie-Kolonii Trzydnik, Woli Trzydnickiej, Rzeczycy Ziemiańskiej (fot. 5). Nieprzypadkowo występują właśnie te daty, które można powiązać z konkretnymi zdarzeniami historycznymi - wydarzeniami rewolucyjnymi i wystąpieniami chłopskimi w guberni lubelskiej w latach 1905-1907. Dochodziło wówczas do strajków, wystąpień i manifestacji, których celem było uzyskanie przez chłopów polepszenia warunków pracy i płacy oraz przywrócenia języka polskiego jako urzędowego. W 1905 roku został

20 Tamże, s. 140-141.

${ }^{21}$ W. Rozynkowski, Kapliczki, figury i krzyże przydrożne w parafii złoczewskiej, Toruń 2004, s. $10-11$. 
wydany tzw. „ukaz tolerancyjny” przyznający chłopom pewne ulgi i przywilej nauczania języka polskiego w szkołach. Ten akt poprzedzony był jednak szeregiem różnorakich form protestu. Ludność wiejska odmawiała pracy na gruntach folwarcznych w okresie prac sezonowych, dochodziło do samowolnego wyrębu lasów czy wypasu bydła na gruntach majątków dworskich. Formą oporu było także organizowane strajków, procesji religijnych, bojkotowanie szkół, sądów i urzędów, gdzie podstawowym językiem był rosyjski. W wyniku tego typu działań wielu protestujących chłopów spotkały represje w postaci aresztowań, czy też kar pieniężnych. Znane są relacje o tego typu akcjach prowadzonych w sąsiednich gminach Dzierzkowice, Gościeradów i Annopol. Krzyż z 1905 roku stojący w polach, na rozstaju dróg wśród pól granicznych między Dąbrową a Kolonią Trzydnik można powiązać właśnie z przedstawionymi wydarzeniami. Ponadto krzyż ten może być znakiem upamiętnienia formowania się nowej miejscowości, jaką była Kolonia Trzydnik, która powstała na dawnych gruntach folwarcznych, które otrzymali chłopi ${ }^{22}$. Według relacji mieszkańców na terenie, gdzie wzniesiono

${ }^{22}$ Jako odpowiedź na represje władz carskich, społeczność wiejska organizowała wystąpienia patriotyczno-religijne: procesje i nabożeństwa, podczas których śpiewano pieśni, recytowano patriotyczne teksty, rozdawano ulotki, prezentowano sztandary z hasłami patriotycznymi i religijnymi. Domagano się wprowadzenia języka polskiego do urzędów gminnych, sądów i szkół. Podczas organizowanych zebrań gminnych podejmowano decyzje, aby nie prenumerować gazet rosyjskich, nie płacić składek i nie organizować transportu dla władz carskich. Takie deklaracje podpisano m.in. w gminie Annopol, Gościeradów, Dierzkowice. Organizowano także strajki szkolne. Niszczono tablice i drogowskazy z napisami w języku rosyjskim (Urzędów, Gościeradów, Dzierzkowice, Annopol). Za: R. Ślusarska, Sytuacja w Guberni Lubelskiej w latach 1905-1908 w świetle materiałów Urzędu Tymczasowego Generat-Gubernatora Lubelskiego, „Annales Universitatis Marie Curie”, 56 (2001) Sectio F, s. 83nn.

Inną formą oporu było zrywanie tablic i zamalowywanie drogowskazów z napisami rosyjskimi. Zamykano również sklepy monopolowe, zawieszano polskie napisy i tablice w urzędach w miejscowościach: Trzydnik, Dąbrowa, Wyżnica, Annopol, Dzierzkowice, Boby, Suchynia. Wydawano pisma rewolucyjne i broszury. Domagano się też podziału lasów - serwitutów. To właśnie prawo do korzystania z lasów dworskich było głównym powodem konfliktu na linii dwór-wieś. Zdarzały się przypadki, kiedy chłopi samowolnie dokonywali wyrębu drzew w lasach dworskich (podkraśnickie wsie Suchyń, Dzierzkowice, Budzyń, Popokowice). Serwituty na tym obszarze wchodziły w skład Ordynacji Zamojskiej. Odmawiano posyłania dzieci do szkół, w których uczono w języku rosyjskim. Zob. A. Koprukowniak, Powiat Janowski w walce o polskość (jesień 1905 r.), w: Z dziejów powiatu kraśnickiego. Materiały sesji, Lublin 1964, s. 214-220; Szymanek, Z dziejów powiatu janowskiego, s. 36.

W styczniu 1905 r. powstało Lubelskie Towarzystwo Rolnicze założone przez ziemian z Lubelszczyzny, które organizowało pogadanki i odczyty dotyczące działalności rolnej i gospodarczej. Powstanie towarzystwa było wynikiem zezwoleń władz carskich wobec polskiego ziemiaństwa, w obliczu rewolucji z 1905 roku. W 1907 roku powstało Towarzystwo Zjednoczonych Ziemianek założone prze Marię Kleniewską z Kluczkowic, które prowadziło akcje mające na celu wzmocnienie ducha narodowego, poprawę oświaty, edukacji, wiedzy o higienie. Czuwano również nad etyczną formacją mieszkańców wsi, organizowano pogadanki na temat ogrodnictwa, pszczelarstwa, rzemiosła ludowego, organizowano kolonie dla dzieci wiejskich, udzielano porad lekarskich. Organizowane były również wiejskie szkoły z językiem polskim. Zob. A. Przegaliński, Społeczna aktywność ziemiaństwa lubelskiego 1905-1914, w: Studia z dziejów ziemian lubelskich w XIX i XX 
krzyż istniał las, który wykarczowano przygotowując grunt pod pola uprawne. Krzyż ustawiono w miejscu skrzyżowania dróg. Do początku XXI wieku dominującym elementem krajobrazowym były dwie wysokie lipy okalające krzyż. Zostały one jednak wycięte przez właściciela pobliskiego pola, a na ich miejscu posadzono dwa żywotniki. Kapliczka utraciła przez to swój walor estetyczny i nie stanowi już dominanty krajobrazowej, która w sposób harmonijny i naturalny komponuje się z otoczeniem. Mieszkańcy dbają o krzyż, odnawiają dekoracje oraz uwzględniają to miejsce $\mathrm{w}$ obchodach świąt kościelnych, podczas procesji czy wielkanocnego święcenia pokarmów.

W Łychowie Gościeradowskim znajduje się krzyż, noszący datę 1905, nazywany przez mieszkańców „krzyżem oficerskim”. Według jednego z opracowań oraz lokalnych podań, znajdować się ma wokół niego mogiła żołnierzy austro-węgierskich poległych podczas potyczki w czasie I wojny światowej w 1914 roku $^{23}$. Informacje takie powtarzają również indywidualni „eksploratorzy”, którzy dzielą się swoimi informacjami na internetowych forach ${ }^{24}$. Zapewne krzyż stanowił pierwotny punkt, wokół którego zdecydowano się założyć mogiłę i pochować poległych. Teren ten został wydzielony z gruntów dworskich jeszcze w latach 30 . XX wieku i przekazany prywatnym właścicielom, w wyniku czego obecnie znajduje się na terenie ogrodu prywatnej posesji. Dlatego pierwotna funkcja krzyża i jego otoczenie są obecnie mało znane. W relacji właściciela posesji, krzyżem interesowali się przed paroma laty inni badacze, którzy mieli przygotować publikację na temat tego krzyża i domniemanej mogiły. Jednak autorom niniejszego arty-

wieku, red. A. Koprukowniak, Lublin 2002, s. 105-136; Rewolucja lat 1905-1907 na Lubelszczyźnie. Wystawa w Oddziale Historii Ruchu Robotniczego im. B. Bieruta, scenariusz M. Gąszczyk, 1 II - 18 IV 1985.

$\mathrm{O}$ znacznym rozdrobnieniu gospodarstw w gminie zob. Z. Mazurek, Opłaty za reforme uwłaszczeniowa w powiecie janowskim, w: Z dziejów powiatu kraśnickiego. Materiały sesji, Lublin 1964, s. 206-213.

${ }^{23}$ Zabytkowe cmentarze i mogiły w Polsce. Województwo tarnobrzeskie, oprac. Marek Florek, Warszawa 1995, s. 93; J. Gurba, Historia ukryta w ziemi. Z przeszłości powiatu kraśnickiego, „Kalendarz Lubelski", 13 (1970), s. 258-263;

W czasie działań wojennych w 1914 roku, krwawe walki austriacko-rosyjskie toczyły się m.in. na linii Polichna-Mniszek-Węglin. Rosjanie zdobyli wieś Księżomierz i wyparli Austriaków w okolicach Olbięcina. Wielka bitwa stoczona pod Kraśnikiem 25 sierpnia 1914 roku, w której walczyło ok. 200 tys. żołnierzy, przyniosła zwycięstwo Austriakom. Rosjanie wycofali się w kierunku Lublina. Jednak we wrześniu wojska rosyjskie rozbiły armię austro-węgierską. W lipcu 1915 roku armia austriacka podjęła kontrofensywę i zajęła powiat janowski, w tym gminę Trzydnik, utrzymując te ziemie aż do roku 1918. Pamięć om licznych bitwach i potyczkach zbrojnych w okolicach Kraśnika (24 sierpnia 1914 pod Olbięcinem), Annopola, Gościeradowa, Zakrzówka, utrwalają zbiorowe mogiły, kurhany, kopce, cmentarze w lasach, przy szosach i w okolicach stacji kolejowych. Szymanek, $Z$ dziejów powiatu janowskiego, s. 42-49.

O miejscach upamiętniających walki podczas powstania styczniowego na terenie gminy Trzydnik (Rzeczyca Księża i Rzeczyca Ziemiańska) zob. A. Polski, A. Kasprzak, Miejsca pamięci powstania styczniowego w województwie lubelskim, Lublin-Fajsławice 2007, s. 78, 106, 147-149, 214; W dniu 6 października 1863 roku odbyła się bitwa pod Węglinem i Wolą Trzydnicką.

${ }^{24} \mathrm{http}: / /$ eksploratorzy.com.pl/viewtopic.php?f=170\&t=10433 (dostęp: 20.08 .2015 ). 
kułu nie udało się ustalić czy powstała publikacja dotyczące tej tematyki. Warto natomiast przywołać inskrypcję wyrytą na kamiennym cokole, która uwiecznia nazwisko fundatora, a przede wszystkim stanowi piękną religijną inwokację. ... (CHRY)STE KŁANIAMY SIĘ/ TOBIE NA KRZYŻU Z/ KORONA CIERNIOWA_/ ZAWIESZONEMU PRO/SIMY CIE ABY KRZYŻ/TWÓJ WYBAWIŁ/ NAS OD WIECZNEGO/ ZATRACENIA AMEN/ TEN KRZYŻ STAWIA/JAN MADEJ DNIA 22 KWIETNIA ROKU 1905. Wedhug wyrytego napisu historia krzyża związana jest z prywatną fundacją z czasów „ukazu tolerancyjnego”, a funkcja mogiły powstańczej została wtórnie przypisana temu miejscu. Obecnie biały, kamienny krzyż zdobi współczesna, niewielka figurka Zbawiciela. Napis wyryty na smukłym filarowym cokole jest niemal nieczytelny, a sam obiekt w bardzo złym stanie zachowania i wymaga natychmiastowej oraz fachowej interwencji konserwatorskiej.

Drugi kamienny, bielony krzyż w Łychowie Gościeradowskim, datowany na rok 1910, wyznacza charakterystyczny punkt w krajobrazie, którym są rozstaje dróg. W tradycji ludowej krzyże i kapliczki ustawiano u początku i na końcu miejscowości, jak i poza nią, na rozwidleniach i na skrzyżowaniach dróg, na skraju lasu, przed mostem lub przeprawą rzeczną. Krzyże przy cmentarzu w Rzeczycy Ziemiańskiej, Rzeczycy Księżej i Owczarni ustawiono u początku dawnych traktów biegnących od kościoła ku innym miejscowościom lub też na drodze wiodącej do cmentarza. Tym samym sakralizowano przestrzeń, wyznaczano obszar, który odgrywał istotną rolę podczas obrzędów religijnych, jak i świeckich np. wyruszenie w podróż. W świadomości wiernych, szczególnie dawniej, obiekty sakralne stanowiły rodzaj apotropaionów, które sakralizując przestrzeń, chroniły jej mieszkańców. Ponadto obiekty sakralne, jak krzyże i kapliczek, stanowiły ważne punkty orientacyjne, informujące o zasięgu dóbr, wyznaczały obszar, z którym identyfikowała się określona społeczność. Ich fundacje, wznoszenie nowych i dekorowanie istniejących obiektów stanowiło przejaw wiary, świadczyło o przywiązaniu do miejsca, wyrażało identyfikowanie się z miejscem, społecznością i życiem religijnym. Odprowadzanie ciała zmarłego w kondukcie pogrzebowym do mogiły lub do ostatniego krzyża na skraju miejscowości traktować należało jako symboliczny rodzaj pożegnania z małą ojczyzną i jej mieszkańcami, również jako symboliczny akt pożegnania się z doczesnościąa25. Mircea Eliade wyjaśnił koncepcje podziału przestrzeni, która ma wymiar zarówno przestrzenny - topograficzny miejsca, jak i czasowy, w rozumieniu pewnych obrzędów, momentów regulujących rytm życia człowieka. Święta, podróże, wyruszenie w drogę, rozpoczęcie siewu, pogrzeb, powrót do domu z działań wojennych, niemal zawsze u progu wszystkich tych wydarzeń istniał jakiś element graniczny, wyznaczający początek lub koniec drogi. Tym elementem w świadomości mieszkańców były małe obiekty sakralne sytuowane w najbliższej przestrzeni życia. Te elementy, ich forma, struktura, patronat, sposób dekoracji były bardzo ściśle związane z lokalną stylizacją, wyznaczały i należały do wewnętrznego świata lokalnej społeczno-

${ }^{25}$ Z. Szromba-Rysowa, Uczta pogrzebowa $w$ zwyczajach $i$ wierzeniach ludowych, PSL, 40 (1986) $\mathrm{nr}$ 1-2, s. 37-38; T. Gajda, Zanikające zwyczaje $i$ wierzenia zwiazane ze śmiercia, PSL, 40 (1986) z.1-2, s. 39-44; J. Mitera, Śmierć na mojej wsi, PSL, 40 (1986) z. 1-2, s. 45-48. 
ści ${ }^{26}$. Archaiczny sposób myślenia determinował wznoszenie kapliczek i krzyży, które poprzez sakralizację przestrzeni, chroniły ją i ludzi przed działaniem złych mocy. Ustawiano je w miejscach oddalenia, w punktach granicznych jak pola, rozstaje dróg, czy na leśne ścieżki, na skraje lasów. Wzniesienie niektórych tego typu obiektów wiązano z dramatycznymi zdarzenia, wierzono, że krzyże w lasach stawiano na miejscach śmierci lub tajemniczych zdarzeń, jak ukazanie się zjaw, czarta itp.

\section{Miejsca pamięci, mogily - ślady wydarzeń historycznych i religijnych ${ }^{27}$}

Do tej grupy obiektów na terenie gminy Trzydnik Duży należą głównie krzyże, często zapomniane, stojące na uboczu, na skraju lasu, w oddaleniu. Daty wyryte na ich trzonach są już niemal zupełnie niewidoczne, tak jak na drewnianym krzyżu we wsi Agatówka. Na ramionach krzyża wyryto inskrypcję BŁOGOSŁAWIENI ZMARLI KTÓRZY UMIERAJĄ W PANU 1945. Krzyż ten stoi na skraju lasu, przy leśnej drodze należącej do szlaku św. Jakuba, a więc na dawnym trakcie pielgrzymim biegnącym z Lublina do Sandomierza. Inny krzyż ustawiono przy mogile w lesie w miejscowości Dąbrowa. Uwiecznia on pamięć o poległym i pochowanym tam niemieckim żołnierzu. Dwa krzyże ustawiono na usypanej mogile, wśród pól w kierunku Agatówki. W Olbięcinie znajduje się również metalowy krzyż, który powstał jako osobista fundacja mieszkańca tej miejscowości Ignacego Hawryło, upamiętniająca członków rodziny, którzy zginęli tragicznie podczas II wojny światowej w 1945 roku.

W odniesieniu do nowszych fundacji, momentem powstania krzyża lub kapliczki były misje święte, czy wizyta Jana Pawła II w Polsce w 1979 roku, którą upamiętnia krzyż drewniany w Agatówce z napisem: BĄDŹ W SERCACH NASZYCH NA PAM. POBYTU JANA PAWŁA II 2 CZE 1979. Drugi, metalowy krzyż ustawiono w 1983 roku na pamiątkę kolejnej wizyty Ojca Świętego w Polsce. Inne postawiono na okoliczność nawiedzenia parafii w Węglinku przez obraz Matki Bożej Częstochowskiej w 2009 roku.

\section{Inskrypcje}

Wartym zauważenia i utrwalenia znakiem czasów są teksty inskrypcji umieszczanych na krzyżach. Emanuje z nich podniosły i poruszający gorliwością wiary wyraz lokalnej pobożności. W tekstach, widniejących na krzyżach i kapliczkach, zawarta jest intencja, prośba lub dziękczynienie, zawierzenie Bogu, Chrystusowi lub Maryi. W wielu przypadkach ujawnia się prywatna intencja fundatora, którym

${ }^{26}$ Krasucki, Krzyże, kapliczki, s. 225, M. Eliade, Traktat o historii religii, przeł. Jan Wierusz-Kowalski, Łódź 1993; tenże, Sacrum-mit-historia. Wybór esejów, wybrał M. Czerwiński, przeł. A. Tatarkiewicz, Warszawa 1974; J. Adamowski, Kategoria przestrzeni w folklorze. Studium etnolingwistyczne, Lublin 1999.

${ }^{27}$ A. Polski, A. Kasprzak, W hołdzie przeszłości - miejsca pamięci powstania styczniowego $w$ województwie lubelskim, Lublin Fajsławice 2012. Publikacja na portalu Lubelskie Korzenie za zgodą autorów. Kwerendę w archiwach przeprowadził A. Kasprzak. http://pomoce.lubgens.eu/articles.php?article_id=129 (dostęp 12.06.2016). 
mogła być jedna rodzina lub też zbiorowa społeczność ${ }^{28}$. Na starych, kamiennych krzyżach odczytać można nazwiska fundatorów i krótkie inwokacje, będące świadectwem ówczesnej pobożności. Warto zacytować wyryte na nich napisy, które w wielu przypadkach są już niemal nieczytelne, bądź niezauważane: BOŻE ZMIŁUJ SIE/NAD NAMI/WYSTWILI/ PAWEŁ I JAN/ LEGOCCY 1905. Biały, murowany krzyż na postumencie stojący wśród pól Rzeczycy Ziemiańskiej przemawia proszalnym głosem: OD POWIETRZA GŁODU OGNIA I WOJNY WYBAW NAS PANIE - FAN DATOR (sic!) JAN MAZURKIEWICZ (fot. 5).

Niezwykle poruszający napis widnieje na krzyżu w miejscowości Wola Trzydnicka: BOŻE/BŁOGO/SŁAW/NAS/MATKO/NIE OPU/SZCZAJ NAS/ZBUDOWANO ROKU/1907 DNIA 25/CZERWCA WM/SIEBIELEC. Kamienny cokół zdobi zabytkowy, metalowy krucyfiks, nieszczęśliwie ukryty pod oplatającą go sztuczną, kwiatową dekoracją. Obiekt ten z racji bardzo bliskiego położenia na zakręcie ruchliwej drogi (trasa nr 855), tuż przy krawędzi jezdni, zatracił swoją wartość kulturową oraz kultową. Obecnie jest właściwie niedostępny, a podejście do niego jest bardzo niebezpieczne. Tego typu położenie uniemożliwia podejmowanie wokół tego obiektu jakiejkolwiek formy kultu. Zatraciła również swą siłę przekazu inskrypcja wyryta na wysokim kamiennym cokole, dziś niemal nieczytelna, zatarta pod licznymi warstwami farby i tynku oraz częściowo zakryta podniesionym znacznie gruntem.

Jedną z dłuższych inwokacji prezentuje krzyż murowany we wsi Dąbrowa-Choiny: JEZU NASZ/ MIŁOSIERNY/ NIECH CIĘ CZCI LUD WIERNY/ BOŻE POCIESZ NIEZMIERNY W CZASIE GŁODU MORU/ OGNIA WOJNY BĄDŹ MIŁOSIERNY/ ROZUM WOLĘ DAJEMY, SERCE OFIARUJEMY/ O JEZU NASZ ZBAWICIELU KOCHAĆ CI/Ę CHCEMY NASZ MILY JEZU/ ZBUDOWANO ROKU 1948.

Szczególny charakter ze względu na tajemnicze okoliczności powstania prezentuje inskrypcja na zabytkowej kapliczce w Rzeczycy Księżej zwieńczonej figurą Matki Bożej Niepokalanej: OD WYHODZCÓW (sic!) Z AMERYKI/ 1 WRZEŚNIA 1907. Niestety mieszkańcom nie jest znana osoba lub osoby fundatorów ani żadne dodatkowe informacje na jej temat. Kapliczka jest wymieniana w gminnym wykazie zabytków.

Osobisty wydźwięk prezentuje napis na krzyżu z Olbięcina fundacji rodziny Hawryłów, upamiętniający rodzinną tragedię:

KATARZYNA HAWRYŁO / ŻYŁA LAT 32 / MARIA HAWRYŁO / ŻYŁA LAT 12 /MARIAN HAWRYŁO /ŻYŁ LAT 10 / POKÓJ ICH DUSZOM / KRZYŻ ŚWIĘTY POSTAWIONO W 1990 / PRZEZ IGNACEGO HAWRYŁE / W INTENCJI RODZINY / ZAMORDOWANYCH W 1945 ROKU

${ }^{28}$ M. Wójcicka, Kapliczkowe inskrypcje - próba analizy typologii, w: Krzyże i kapliczki przydrożne jako znaki społecznej, kulturowej i religijnej pamięci, red. J. Adamowski, M. Wójcicka, Lublin 201, s. 81-93. 


\section{Przyroda wokól przydrożnych obiektów sakralnych}

Coraz częściej zatracane i zniekształcane bywa otoczenie przyrodniczo-krajobrazowe obiektów sakralnych. Bliskie sąsiedztwo tablic ogłoszeniowych, słupów elektrycznych, budynków i ogrodzeń powoduje, że kapliczki stają się niezauważalne wśród tych elementów krajobrazu. Ponadto wycinka drzew i nasadzanie żywotników, a także zastępowanie elementów przyrodniczych poprzez wprowadzanie sztucznych dekoracji sprawia, że obiekty te przestają odgrywać jakąkolwiek rolę w krajobrazie miejsca. Zostają przytłoczone współczesnymi elementami otoczenia i giną w chaosie przestrzennym. Nieocenionym więc źródłem wiedzy i materiałem porównawczym są stare zdjęcia prezentujące dawny wygląd obiektu i jego otoczenia.

Negatywnym wnioskiem wynikającym z przeprowadzonej kwerendy jest fakt, że kilka starych obiektów zostało pozbawionych swego pierwotnego przyrodniczego dopełnienia. Do tych obiektów należą: krzyż na polach w Dąbrowie, krzyż w Dąbrowie Choiny, wycinka lip przy kapliczce w Dąbrowie, wycinka drzew w Łychowie wokół kapliczki Wójcików i wokół kapliczki Płechów oraz wokół historycznej kapliczki Matki Bożej Częstochowskiej w Rzeczycy Księżej datowanej na rok 1906, którą jeszcze w 2004 roku okalały dorodne kasztanowce, by ustąpić miejsca zimozielonym krzewom.

\section{Kapliczki i krzyże przydrożne we współczesnych praktykach religijnych}

W życiu religijnym małych społeczności, głównie wiejskich, mocno kultywowane są obrzędy odbywające się wokół lokalnych obiektów sakralnych. Należą do nich wielkanocne święcenie pokarmów, nabożeństwa majowe, poświęcenie pól, uroczyste procesje, obrzędy pogrzebowe. Okresowe strojenie kapliczek rozpoczyna się wczesną wiosną, kiedy zmieniane są dekoracje, sztuczne bukiety i girlandy bywają zastępowane żywymi bukietami i donicami lub nasadzeniami. Odświeżane bywają elewacje, ogrodzenia. Momentem przełomowym jest Wielkanoc, następnym okresem jest maj, kiedy odprawiane są nabożeństwa majowe (tzw. majówki). Kolejne ważne momenty to Zesłanie Ducha Świętego (tzw. Zielone Świątki) i Uroczystość Najświętszego Ciała i Krwi Chrystusa (tzw. Boże Ciało), Święto Wniebowzięcia Najświętszej Marii Panny (tzw. Matki Bożej Zielnej, 15 sierpnia) czy też święto odpustowe parafii. Od niedawna do cyklicznych praktyk religijnych należą również procesje fatimskie, organizowane w środę po 13 dniu każdego miesiąca, od maja do października. Ich celem są najbliższe kościołowi parafialnemu lub filialnemu kapliczki lub krzyże.

Wspólna dbałość o udekorowanie kapliczek lub krzyży oraz udział mieszkańców w tych uroczystościach staje się momentem sprzyjającym integracji społecznej, buduje poczucie tożsamości i wzmacnia identyfikację z miejscem ${ }^{29}$. Optymistycznym wnioskiem wynikającym z przeprowadzonej kwerendy i obser-

${ }^{29}$ A. Gaweł, Przydrożne krzyże i kapliczki na Sokólszczyźnie jako dawne i wspótczesne „akty wiary" ludu wiejskiego, w: Krzyże i kapliczki przydrożne jako znaki społecznej, kulturowej i religijnej pamięci, red. J. Adamowski, M. Wójcicka, Lublin 2011, s. 229-243; M. Jechna, A. Ćirlić, Kapliczki jako miejsca odwieczne. Społeczna egzystencja kapliczek i krzyży przydrożnych w okolicy 
wacji jest zauważona dbałość mieszkańców o stan zachowania małych obiektów sakralnych i spontanicznie przeprowadzane prace remontowe, modernizacje i naprawy usterek ${ }^{30}$. Pewne zastrzeżenia mogą budzić niektóre procesy upiększania i dekoracje tych miejsc. W przeważającej grupie ozdobą kapliczek i krzyży są sztuczne kwiaty o krzykliwej kolorystyce, stosowane z nadmiarem i w efekcie przysłaniające historyczną i artystyczną wartość obiektów. Zastrzeżenia może budzić też nagromadzenie świątków i wizerunków kultowych, które przemieszane ze sztucznymi kwiatami i bukietami tworzą estetyczny, ale i dewocyjny chaos, czego przykład może stanowić wnętrze kapliczki w Łychowie Szlacheckim. Takie zjawiska można tłumaczyć przywiązaniem społeczności do charakteru wystroju i znajdujących się we wnętrzu wizerunków kultowych, którymi są obraz lub figurka lub też kilka tego typu obiektów dewocyjnych (Korea, Łychów, Rzeczyca Ziemiańska kapliczka Gładkowskich). Należy jednakże zauważyć, że brak powszechnej wiedzy o tym, co istotnie jest obiektem wartościowym historycznie i artystycznie mogło uchronić wiele wizerunków przez rabunkiem lub niefrasobliwym usunięciem. Obawę mogą natomiast budzić nieprofesjonalne konserwacje i zabiegi naprawcze, jakie podejmuje lokalna społeczność, w wyniku których wiele obiektów nieodwracalnie może utracić swoją pierwotną formę zabytkową i wartość estetyczną. Niechlubnym przykładem jest rzeźba św. Floriana z kapliczki w Rzeczycy Ziemiańskiej, która została pokryta polichromią, zupełnie wypaczając stylistykę figury.

Brak właściwego nadzoru konserwatorskiego zagraża również malowidłom pokrywającym ściany w kapliczce fundacji małżeństwa Wójcików w Łychowie Gościeradowskim. Architektoniczna konstrukcja tego historycznego obiektu, datowanego na rok 1847, wymaga pilnej interwencji konserwatorskiej. Ściany kapliczki pokrywa wilgoć, odpada tynk, w murze widoczne są wyraźne pęknięcia i ubytki. Według relacji mieszkańców malowidła były już odnawiane, ale wykonała je osoba nie posiadająca w tym zakresie właściwego przygotowania. Widoczne jest to w stanie zachowania polichromii, niektóre elementy są zatarte, słabiej widoczne lub odtworzone pobieżnie, znacznych fragmentów dekoracji brakuje, gdyż odpadły wraz z tynkiem.

Świadectwem dbałości mieszkańców o przydrożne obiekty sakralne jest historia kapliczki domkowej w Korei k. Rzeczycy Księżej. Budowla w 1951 roku została przeniesiona ze swojego pierwotnego miejsca w wąwozie, do wyżej położonej części miejscowości. Ponieważ w wąwozie wydobywano piach, kapliczce zaczęły zagrażać postępujące ubytki podłoża. Dlatego też mieszkańcy zdecydowali o jej relokacji. Według relacji napotkanego świadka, budowniczym kapliczki był pan Piekut z Korei. Kapliczka posiada wyjątkową strukturę architektoniczną, niespotykaną w tego typu obiektach w gminie Trzydnik Duży. Jej szczyt tworzą trzy trójkątne występy, ponad drzwiami wyraźnie oddziela się profilowany gzyms. We wnętrzu ustawiono niewielkie figurki św. Antoniego z Dzieciątkiem

wsi Ostatówek koło Szydłowca, w: Krzyże i kapliczki przydrożne jako znaki społecznej, kulturowej i religijnej pamięci, red. J. Adamowski, M. Wójcicka, Lublin 2011, s. 257-265.

${ }^{30} \mathrm{~W} 2016$ roku przeprowadzono remont kapliczki w Korei. W 1989 roku wymieniono pokrycie dachu kapliczki w Dąbrowie, a w 2009 roku ogrodzenie. 
Jezus oraz Madonny. Kapliczka jest stale odnawiana, zmianie uległa kolorystyka elewacji. Przekształcono także zieleń, likwidując okalające ją jarzęby pospolite ${ }^{31}$ i zastąpiono je żywotnikami.

Na podstawie przeprowadzonej kwerendy udało się ustalić kilka faktów historycznych związanych z fundacjami i okolicznościami powstania kapliczki czy krzyża. Jednak wiele informacji pozostaje niejasnych ze względu na brak osób, które mogłyby dać świadectwo ustne o historii. Śmierć starszych osób, brak ciągłości w przekazywaniu tradycji ustnej to ważny problem kulturowy, ponieważ powoduje to zubożenie wiedzy na temat najbliższego otoczenia i braku świadomości o znaczeniu tych obiektów dla historii miejsca i jego mieszkańców. Pozytywnym spostrzeżeniem dotyczącym większości obiektów jest dbałość mieszkańców o krzyże i kapliczki, troska o dekoracje, odświeżanie wystroju, nierzadko umieszczanie świeżych bukietów, wymiana wstążek i dekoracji ze sztucznych kompozycji, odnawianie ogrodzeń, by zabezpieczyć dostęp do kapliczki lub krzyża. W ostatnich latach, co potwierdzają relacje napotkanych osób, zaprzestano odprawiania nabożeństw przy kapliczkach i krzyżach, głównie Litanii Loretańskiej tzw. majówek. Świadkowie zgodnie przyznawali, że „dawniej zawsze odprawiano majowe”. Mieszkańcy zbierali się wówczas wokół kapliczki lub krzyża, a wśród nich byli zarówno starsi, jak i młodsze pokolenie ${ }^{32}$. Obecnie tylko nieliczne obiekty są miejscem i celem tej ludowej religijnej adoracji, którą praktykują już wyłącznie osoby starsze. Współcześnie znaczenie religijno-kulturowe kapliczek i krzyży uwzględnia się tylko podczas procesji „poświęcania pól” lub w czasie obchodów święta Bożego Ciała. Ponadto krzyż stojący na granicy, na skraju miejscowości jest punktem, do którego podczas pogrzebu mieszkańcy idą pieszo, by z szacunkiem odprowadzić kondukt z ciałem zmarłego.

Niepokojącym jest, że te ważne historycznie obiekty są często w bardzo złym stanie. Niektóre zapomniane, pozbawione konserwacji chylą się ku ziemi. Ponure wrażenie robią odłamane ramiona krzyży, pogruchotane postumenty, uszkodzone obrazy i figury kultowe, zaniedbane dekoracje. Negatywny efekt estetyczny wywołuje nagromadzenie obrazków i figurek o niskiej wartości artystycznej, jak i kultowej. Te zjawiska są objawem zarówno dbałości, jak i naiwnej pobożności, która przejawia się w mnożeniu świątków, obrazków i figurek. Nierzadko dekoracja w postaci sztucznych kwiatów umieszczana jest w nadmiarze, tak, że przysłania istotne $z$ historycznego punktu widzenia informacje. Wiele napisów jest zatartych lub zamalowanych kilkoma warstwami farby lub też zasypanych warstwami gruntu (napis na krzyżu w Woli Trzydnickiej). Niektóre napisy zostały odtworzone w sposób niepełny lub nawet błędny. Jednym z wartościowych, lecz zaniedbanych obiektów jest krzyż kamienny leżący na prywatnej posesji w Łychowie Gościeradowskim z 1905 roku, określany wśród lokalnej społeczno-

${ }^{31}$ Relacja Heleny Farbisz ze strony miejscowości Rzeczyca Księża na portalu Facebook. Relacja $z$ dn. 22.02.2015. (dostęp: 15.10.2015).

${ }^{32}$ Jeszcze w latach 90. XX wieku młodzież i dzieci odprawiały nabożeństwo majowe przy kapliczce w Dąbrowie. Wtedy też do kapliczki przyniesione zostały drobne wizerunki kultowe, świece i inne elementy wyposażenia. Relacja ustna mieszkańca uzyskana przez autorów tekstu podczas badań terenowych w 2015 roku. 
ści „krzyżem oficerskim”. Mocno uszkodzoną i bez szans na ratowanie pozostaje kapliczka w Owczarni (fot. 4). Potężna lipa, na której umieszczono ołtarzykową gotycyzującą nastawę, jest bardzo uszkodzona. Tuż obok w 2012 lub 2013 roku postawiono ceglaną kapliczkę domkową, do której przeniesiono figurę Matki Bożej oraz krucyfiks, które pierwotnie znajdowały się w drewnianej nastawie na lipie. Stara kapliczka związana z drzewem została skazana na stopniowe niszczenie, a wkrótce na niebyt, a jej trwanie wyznacza tylko żywotność lipy. Dużą stratą o charakterze historycznym i kulturowym dla tego miejsca będzie zniszczenie tej ołtarzykowej konstrukcji. Według relacji jednego z mieszkańców, dawniej przy kapliczce odbywały się majówki, święcono pokarmy wielkanocne, odbywały się procesje poświęcania pól. Niestety nowy obiekt swoją strukturą architektoniczną ani też roślinnym dopełnieniem nie tworzy tego rodzaju obszaru sacrum, jaki emanował z kapliczki lipowej. Surowy, architektoniczny konstrukt nie ma nic wspólnego ze stylistyką dawnych kapliczek domkowych i do nich nie nawiązuje. Trudno uwierzyć, że tak blisko zestawione obok siebie dwa odmienne twory nie wzbudzają refleksji mieszkańców i starań, by przywrócić dawne piękno i wrażenie sacrum, tak charakterystyczne dla starych kapliczek i krzyży.

Jak pisał Wiktor Zin, jeszcze przed II wojną światową, istniały w Polsce warsztaty trudniące się wyrobem drewnianych kapliczek, figur, szafek z przedstawieniami świętych lub z podkolorowanymi oleodrukami, które następnie sprzedawano na jarmarkach i odpustach ${ }^{33}$. Dziś trudno poszukiwać takich miejsc i osób. Twórcy ludowi rzeźbią świątki, które znajdują uznanie u miłośników ludowości i wzbogacają ich prywatne kolekcje. Natomiast w nowych lub odnawianych kapliczkach oblicza świętych patrzą na nas z fabrycznych reprodukcji i gipsowych lub figurek z tworzyw sztucznych. Stare drewniane kapliczki, szafki i krzyże zastępowane są przez nowe obiekty i dewocjonalia, ale często pozbawione uroku, jaki reprezentowała ludowa, drewniana ciesiołka ${ }^{34}$. Tak jak zanika drewniana architektura mieszkalna, rzadkością staje się rzeźba ludowa umieszczana w kapliczkach i na krzyżach.

Pozytywnym akcentem w zakresie troski o obiekty kultu jest fakt podejmowania lokalnych inicjatyw, mających na celu ratowanie zabytków. Tego typu zjawisko ma miejsce w Łychowie Gościeradowskim, gdzie zawiązano lokalne stowarzyszenie, które zbiera fundusze na odnowę kapliczki rodziny Wójcików.

Zjawiskiem niosącym nadzieję na ocalenie pamięci o historii przydrożnych obiektów sakralnych jest rosnące zainteresowanie wśród miejscowej społeczności lokalną historią i jej zabytkami, w tym obiektami sakralnymi. Efektem działania stowarzyszeń, niewielkich grup, czy indywidualnej inicjatywy są strony internetowe poświęcone miejscowościom oraz profile zakładane na łamach portali społecznościowych. Zrzeszają one obecnych mieszkańców i sympatyków tego typu tematyki, jak i tych, którzy wyemigrowali, a którym stale bliska jest rodzinna

${ }^{33}$ W. Zin, Opowieści o polskich kapliczkach, Wrocław Warszawa Kraków 1995, s. 62-63. Autor wspomina jeden z takich warsztatów, działający ok. 1935 roku na terenach między Hrubieszowem a Chełmem. Michał Olechwir - Hrubieszów, rzeźbiarz świątków i kapliczek

${ }^{34}$ T. Chrzanowski, K. Piwocki, Drewno w dawnej architekturze i rzeźbie ludowej, Wrocław 1981. 
miejscowość. Publikowane na stronach zdjęcia, prywatne wspomnienia i opowieści pozwalają odtworzyć przeszłe wydarzenia oraz zobaczyć historyczne fotografie pochodzące ze zbiorów prywatnych ${ }^{35}$. Takim źródłem związanym pośrednio z gminą Trzydnik Duży są profile Facebook: „Kraśnik na starych zdjęciach” oraz „Kraśnik i okolice”, a także profil „Rzeczyca Księża”, na których umieszczono również album lokalnych kapliczek i krzyży ${ }^{36}$. Oprócz aktualnych zdjęć są fotografie archiwalne ze zbiorów prywatnych. Dzięki takim inicjatywom możliwe jest odtworzenie lokalnej historii, której niemym bohaterem jest często sceneria, otoczenie, architektura w tle. Współcześnie kapliczki często wyglądają zupełnie inaczej lub też wiele obiektów już nie istnieje, a dzięki zdjęciom możemy je zidentyfikować i przywołać związane z nimi wspomnienia.

słowa kluczowe: kapliczka; krzyż przydrożny; gmina Trzydnik Duży; zabytek; obiekt sakralny; krzyż postumentowy; kultura; historia; religijność

\section{BIBLIOGRAFIA}

\section{Opracowania}

Adamowski J., Kategoria przestrzeni $w$ folklorze. Studium etnolingwistyczne, Lublin 1999.

Baca A. ks., Historia i teraźniejszość. Parafia Rzymsko-katolicka pw. Przemienienia Pańskiego w Rzeczycy Ziemiańskiej, Sandomierz 2007.

Baranowski Z.Ł., Figury, krzyże i kapliczki przydrożne w powiecie janowskim, „Janowskie Korzenie. Pismo regionalne ziemi janowskiej”, 9 (2007) s. 61-91.

Bujak A., Krzyż polski, Krajobraz i sacrum, t. 3, Kraków 2011.

Chrzanowski T., Piwocki K., Drewno $w$ dawnej architekturze i rzeźbie ludowej, Wrocław 1981.

Czerwińska K., Dawne i wspótczesne role matej architektury sakralnej w społecznościach lokalnych (na przykładzie Śląska Górnego i Cieszyńskiego), w: Krzyże i kapliczki przydrożne jako znaki społecznej, kulturowej i religijnej pamięci, red. J. Adamowski, M. Wójcicka, Lublin 2011, s. 141-153.

Ćwik Wł., Reder J., Lubelszczyzna. Dzieje rozwoju terytorialnego, podziałów administracyjnych i ustroju władz, Lublin 1977.

Eliade M., Traktat o historii religii, przeł. Jan Wierusz-Kowalski, Łódź 1993.

Eliade M., Sacrum - mit - historia. Wybór esejów, wybrał M. Czerwiński, przeł. Anna Tatarkiewicz, Warszawa 1974.

Gajda T., Zanikajace zwyczaje $i$ wierzenia zwiazane ze śmiercia, „Polska Sztuka Ludowa - Konteksty", 40 (1986) z.1-2, s. 39-44.

${ }^{35}$ Zainteresowanie historią i kulturą regionalną wśród badaczy, jak i w społecznościach lokalnych od wielu lat jest bardzo duże. Z. Mańkowski, O uprawianiu $i$ znaczeniu historii regionalnej, „Region Lubelski”, 4 (6) 1989-1990, s. 107-109. Jest to recenzja materiałów z konferencji naukowej Historia regionalna - jej miejsce w świadomości społecznej, Toruń 6-7 kwietnia 1990, Ciechanów-Toruń 1991. Kongres Regionalnych Towarzystw Kultury 1990 odbył się w Lublinie.

${ }^{36} \mathrm{https}: / /$ pl-pl.facebook.com/krasnik.starezdjecia/ (dostęp: 20.08.2016).

https://pl-pl.facebook.com/Kra\%C5\%9Bnik-i-okolice-998362256865094/ (dostęp: 20.08.2016)

https://pl-pl.facebook.com/Rzeczyca-Ksi\%C4\%99\%C5\%BCa-184029581627990/nb (dostęp:

20.08.2016 
Garbacz K., Na szlaku biłgorajskich kapliczek i krzyży przydrożnych, Zielona Góra 2009.

Gauda A., Ludowe krzyże żelazne na Lubelszczyźnie, „Studia i Materiały Lubelskie”, 12 (1987) s. 109-144.

Gaweł A., Przydrożne krzyże i kapliczki na Sokólszczyźnie jako dawne i wspótczesne ,, akty wiary" ludu wiejskiego, w: Krzyże i kapliczki przydrożne jako znaki społecznej, kulturowej i religijnej pamięci, red. J. Adamowski, M. Wójcicka, Lublin 2011, s. 229-243

Gaweł A., Przydrożne krzyże i kapliczki na Sokólszczyźnie jako dawne i wspótczesne ,, akty wiary" ludu wiejskiego, w: Krzyże i kapliczki przydrożne jako znaki społecznej, kulturowej i religijnej pamięci, red. J. Adamowski, M. Wójcicka, Lublin 2011, s. 229-243;

Gurba J., Historia ukryta w ziemi. Z przeszłości powiatu kraśnickiego, „,Kalendarz Lubelski”, 13 (1970) s. 258-263.

Ilcewicz E. bp, Święta Otylia patronka Urzędowa, Urzędów 1999, s. 11-12.

Jechna M., Ćirlić A., Kapliczki jako miejsca odwieczne. Społeczna egzystencja kapliczek i krzyży przydrożnych w okolicy wsi Ostałówek koło Szydlowca, w: Krzyże i kapliczki przydrożne jako znaki spolecznej, kulturowej i religijnej pamięci, red. J. Adamowski, M. Wójcicka, Lublin 2011, s. 257-265.

Jodłowska J., Kapliczki i krzyże w gminie Jastków jako ,świadkowie zdarzen’”, w: Krzyże i kapliczki przydrożne jako znaki spotecznej, kulturowej i religijnej pamięci, red. J. Adamowski, M. Wójcicka, Lublin 2011, s. 295-300.

Kapliczki i krzyże przydrożne w gminie Michów (folder promocyjny), red. Janina i Marian Wicha, Michów 2015.

Kapliczki i krzyże przydrożne w pejzażu Ziemi Garbowskiej, red. R. Bartnik, M. Wylaź, Z. Małyszek, Lublin 2014.

Kobojek S., Polskie kapliczki, Warszawa 2008

Kondraciuk P., Urbański A., Kapliczki, figury i krzyże przydroże w pejzażu pogranicza, Lublin Zamość 2008

Koprukowniak A., Powiat Janowski w walce o polskość (jesień 1905 r.), w: Z dziejów powiatu kraśnickiego. Materiaty sesji, Lublin 1964, s. 214-220.

Krasucki W., Krzyże i kapliczki przydrożne jako znaki podziału przestrzeni, „Polska Sztuka Ludowa", 40 (1986) nr 3-4 s. 225-232.

Kucharzak J., Krzyże i kapliczki Łukowa i okolic jako świadkowie lokalnych wydarzeń, w: Krzyże i kapliczki przydrożne jako znaki społecznej, kulturowej i religijnej pamięci, red. J. Adamowski, M. Wójcicka, Lublin 2011, s. 309-319.

Kulesza P., M. Lubiarz, Przydrożne obiekty sakralne w gminie Metgiew (woj. Lubelskie) - analiza kulturowo-krajobrazowa, w: Obiekty religijne w krajobrazie, red. J. Plit, Sosnowiec 2013, s. 127-140.

Lipski Z., Kapliczki i krzyże przydrożne w parafii Dabrowica, Lublin 2000.

Ławicka A., Krzyże drewniane z insygniami Męki Pańskiej na Lubelszczyźnie, „Twórczość Ludowa", 4 (2000) s. 7-10.

Łukasiewicz J., Drogowskazy wiary. Krzyże i kapliczki ziemi janowskiej, Zamość 2011.

Małe ojczyzny Polaków. Łychów Gościeradowski. Łychów Szlachecki, opracowała Józefa Zofia Pytlak, rkp.

Mańkowski Z., O uprawianiu i znaczeniu historii regionalnej, „Region Lubelski”, 4(6) 1989-1990, s. 107-109.

Mazurek Z., Oplaty za reformę uwłaszczeniowa w powiecie janowskim, w: $Z$ dziejów powiatu kraśnickiego. Materiaty z sesji naukowej, pod red. K. Myślińskiego, R. Szaflika, Lublin 1963, s. 206-213.

Mitera J., Śmierć na mojej wsi, „Polska Sztuka Ludowa - Konteksty”, 40 (1986) z. 1-2, s. $45-48$. 
Petera J., Kapliczki drewniane na Lubelszczyźnie, „Z zagadnień kultury ludowej”, 2-3 (1981) s. 63-106.

Petera-Górak J., Kapliczki i krzyże przydrożne, w: Dziedzictwo kulturowe Lubelszczyzny. Kultura Ludowa, red. A. Gauda, Lublin 2001, s. 21-28.

Pękalski M., Kapliczki i krzyże w Urzędowie, „Z bliska i z daleka”, 6 (57), 1938 nr 9, s. 260.

Pękalski, Drewniane kapliczki nagrobne w powiecie bitgorajskim, „Polska Sztuka Ludowa", 15 (1961) nr 2, s. 94-96.

Piękno kapliczek, figur i krzyży przydrożnych - gmina Puławy, oprac. i red. M. Pasik, Góra Puławska 2014.

Polski A., Kasprzak A., Miejsca pamięci powstania styczniowego w województwie lubelskim, Lublin-Fajsławice 2007.

Powiłańska D., Kapliczki i krzyże przydrożne w Biłgorajskim w fotografii Piotra Maciuka, „Studia i Materiały Lubelskie”, 14 (1997) s. 157-162.

Powiłańska-Mazur D., Kapliczki św. Mikołaja na Lubelszczyźnie, „Twórczość Ludowa”, 20, (2005) nr 1-4, s. 65-67.

Powiłańska-Mazur D., Patron powodzian, tonacych, spowiedników, mostów: o rzeźbach św. Jana Nepomucena $w$ regionie lubelskim, „Twórczość Ludowa”, 19 (2004) nr 4 s. $16-18$.

Przegaliński A., Społeczna aktywność ziemiaństwa lubelskiego 1905-1914, w: Studia $z$ dziejów ziemian lubelskich w XIX i XX wieku, red. A. Koprukowniak, Lublin 2002, s. $105-136$.

Reder J., Powiat kraśnicki (rys historyczny), w: Z dziejów powiatu kraśnickiego. Materiaty z sesji naukowej, red. K. Myśliński, R. Szaflik, Lublin 1963, s. 186-190.

„Regionalista” Czasopismo Kraśnickiego Towarzystwa Regionalnego, 17 (2001).

Rozynkowski W., Kapliczki, figury i krzyże przydrożne w parafii złoczewskiej, Toruń 2004.

Skibiński S., Kapliczki i światki powiatu chetmskiego $w$ świetle źródet archiwalnych, „Polska Sztuka Ludowa”, 4 (1967) s. 223-241.

Stownik Geograficzny Królestwa Polskiego i innych krajów słowiańskich, Warszawa T. VII 1886, T. X 1889, T. XII 1892, T. XIII 1893.

Suchora B., Dzieje Parafii Przemienienia Pańskiego w Rzeczycy Ziemiańskiej w latach 1945-1992, Lublin 1998, mps Archiwum KUL.

Szromba-Rysowa Z., Uczta pogrzebowa $w$ zwyczajach $i$ wierzeniach ludowych, „Polska Sztuka Ludowa", 40 (1986) nr 1-2, s. 37-38.

Szykuła A., Kapliczki i figury przydrożne św. Jana Nepomucena na terenie gminy Labunie, „Zamojski Tygodnik Kulturalny”, 1-2 (2006) s. 62-68.

Szykuła A., Obiekty sakralne i figury św. Jana Nepomucena w krajobrazie gminy Zamość, „Zamojski Kwartalnik Kulturalny”, 3 (96) 2008, s. 18-21.

Szymanek W., Z dziejów powiatu janowskiego i kraśnickiego w latach 1474-1975, Lublin 2003.

Ślusarska R., Sytuacja w Guberni Lubelskiej w latach 1905-1908 w świetle materiałów Urzędu Tymczasowego Generat-Gubernatora Lubelskiego, „Annales Universitatis Marie Curie", 56 (2001) Sectio F, s. 83-112.

Tymochowicz M., Patroni kapliczek przydrożnych z obszaru Lubelszczyzny, w: Obiekty religijne w krajobrazie, red. J. Plit, Sosnowiec 2013, s. 141-150.

Wójcicka M., Kapliczkowe inskrypcje - próba analizy typologii, w: Krzyże i kapliczki przydrożne jako znaki społecznej, kulturowej i religijnej pamięci, red. J. Adamowski, M. Wójcicka, Lublin 201, s. 81-93. 
Z dziejów powiatu kraśnickiego. Materiaty z sesji naukowej, pod red. K. Myślińskiego, R. Szaflika, Lublin 1963.

Zabytkowe cmentarze i mogity w Polsce. Województwo tarnobrzeskie, oprac. Marek Florek, Warszawa 1995.

Zabytkowe kapliczki w gminie Urzędów, Urzędów 2014.

Zin W., Opowieści o polskich kapliczkach, Wrocław-Warszawa-Kraków 1995.

Żurawicka G., Kapliczki w krajobrazie, „Zamojski Tygodnik Kulturalny”, 3 (1995), s. 9-11.

Życzyńska-Bajek Z., Bajek M., Peretki architektury. Kapliczki okolic Stalowej Woli, Stalowa Wola 2005.

\section{Netografia}

http://eksploratorzy.com.pl/viewtopic.php?f=170\&t=10433 (dostęp: 20.08.2015).

Polski A., Kasprzak A., W holdzie przeszłości - miejsca pamięci powstania styczniowego $w$ województwie lubelskim, Lublin Fajsławice 2012. Publikacja na portalu Lubelskie Korzenie za zgodą autorów. Kwerendę w archiwach przeprowadził Andrzej Kasprzak. http://pomoce.lubgens.eu/articles.php?article_id=129 (dostęp: 12.06.2016).

https://www.facebook.com/Rzeczyca-Ksi\% $\%$ C4\% $999 \%$ C5\%BCa-184029581627990/?fref=ts (dostęp 25.08.2016).

https://pl-pl.facebook.com/krasnik.starezdjecia/ (dostęp: 20.08.2016).

https://pl-pl.facebook.com/Kra\%C5\%9Bnik-i-okolice-998362256865094/(dostęp: 15.07.2016).

\section{CULTURAL, HISTORICAL, AND RELIGIOUS VALUE OF ROADSIDE ALTARS AND CROSSES IN THE TRZYDNIK DUŻY COMMUNE}

\section{Summary}

In July and August of 2015 in the area of the Trzydnik Duży commune, a field study was carried out, regarding sacral roadside monuments. Observations concerning the condition of the inventoried objects were recorded during the analyses. Inscriptions and vital information relating to the history and religious practices found on these objects were also noted. The sacral objects and their surroundings were photographed. What is more, interviews were carried out with passers-by about the history of the studied objects. As a result of this study 73 roadside sacral objects were inventoried, including 17 houseshrines and cabinet shrines. The remaining objects are wooden, and metal crosses, as well as two statues of Virgin Mary. The study was pioneer in character, since a complex inventory of sacral objects in the Trzydnik Duży commune had not been performed before. The historical-cultural or natural value of these objects had not been investigated. Therefore, the aim of this study was to highlight and preserve their historical value. Their artistic and architectural forms, as well as cultural and religious meaning in the history of the Trzydnik Duży commune were brought to attention.

Key words: shrine; roadside cross; Trzydnik Duży commune; historic monument; sacral object; pedestal cross; culture; history; religiousness 


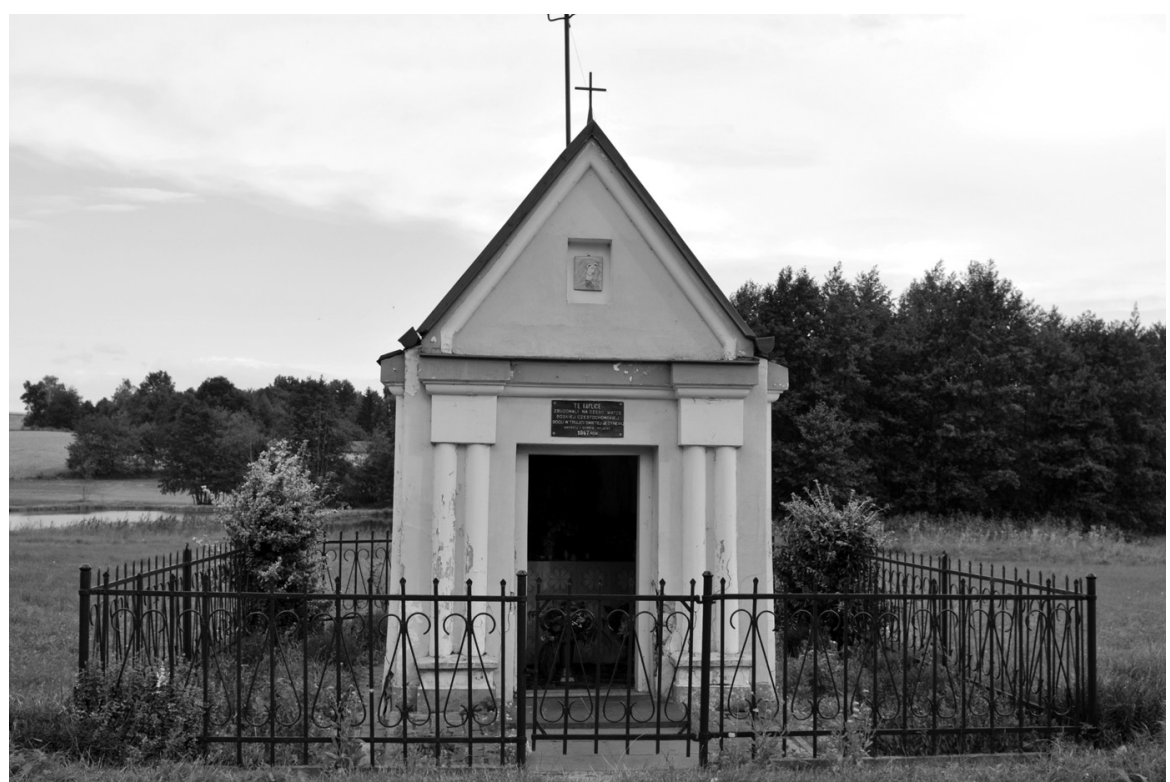

Fot. 1. Kapliczka Matki Boskiej Częstochowskiej w Łychowie Gościeradowskim, fundacja Andrzeja i Doroty Wójcików, 1847 r. Fot. Magdalena Lubiarz.

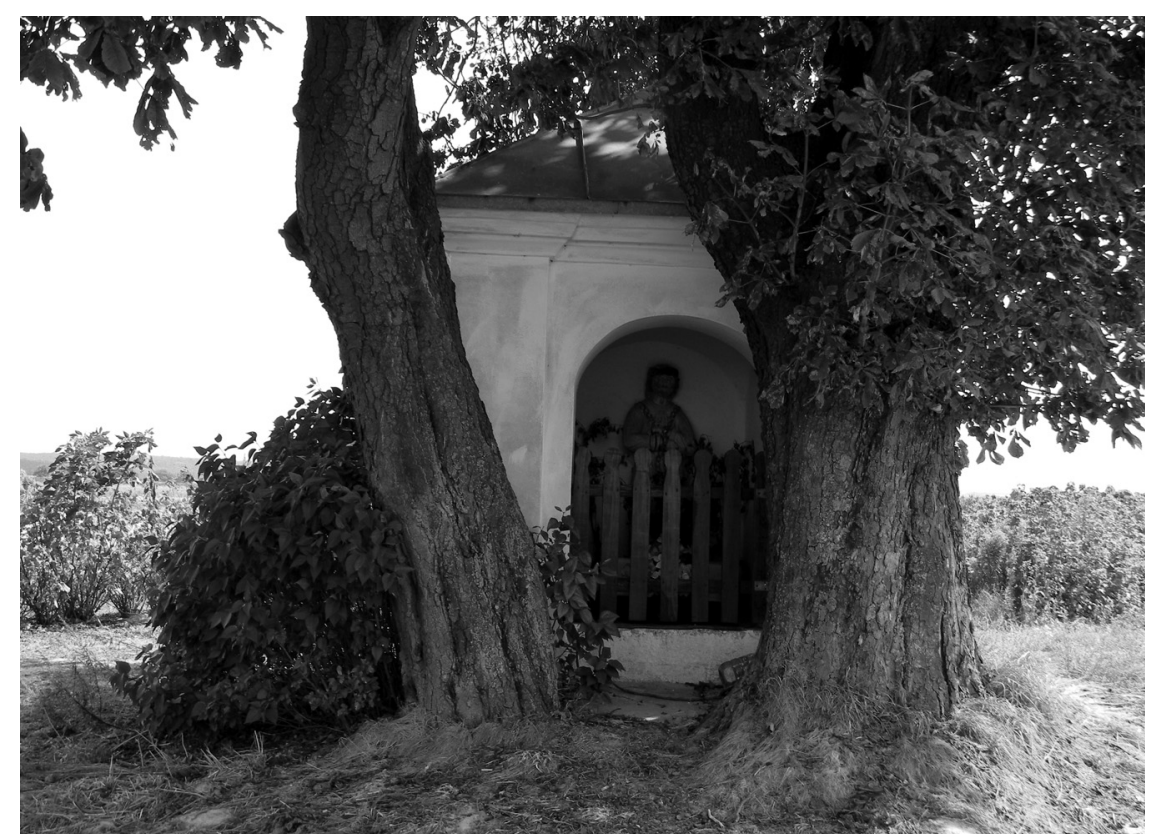

Fot. 2. Kapliczka domkowa w Owczarni.

Fot. Magdalena Lubiarz. 


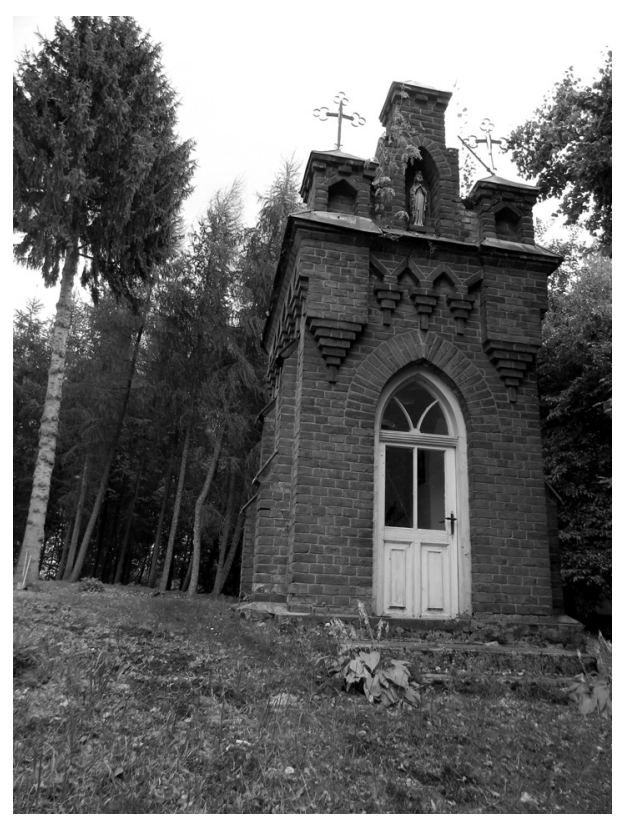

Fot. 3. Kapliczka rodziny Gładkowskich w Rzeczycy Ziemiańskiej. Fot. Małgorzata Żak-Kulesza.

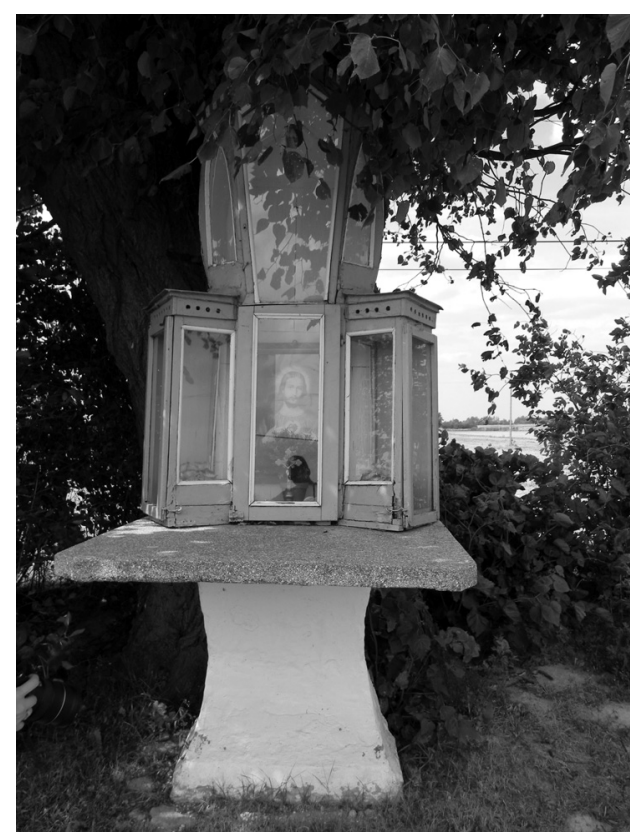

Fot. 4. Kapliczka szafkowa w Owczarni. Fot. Małgorzata Żak-Kulesza. 


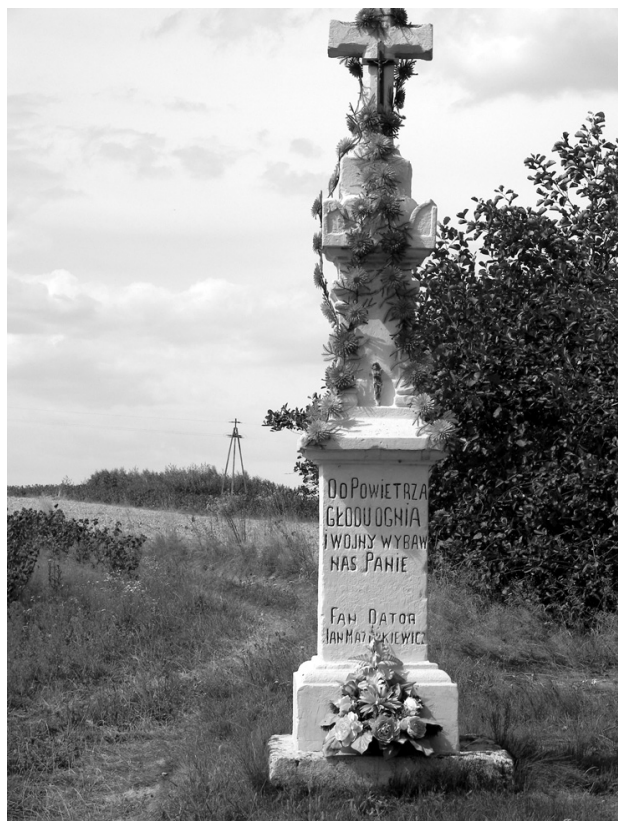

Fot. 5. Krzyż postumentowy w Rzeczycy Ziemiańskiej. Fot. Małgorzata Żak-Kulesza.

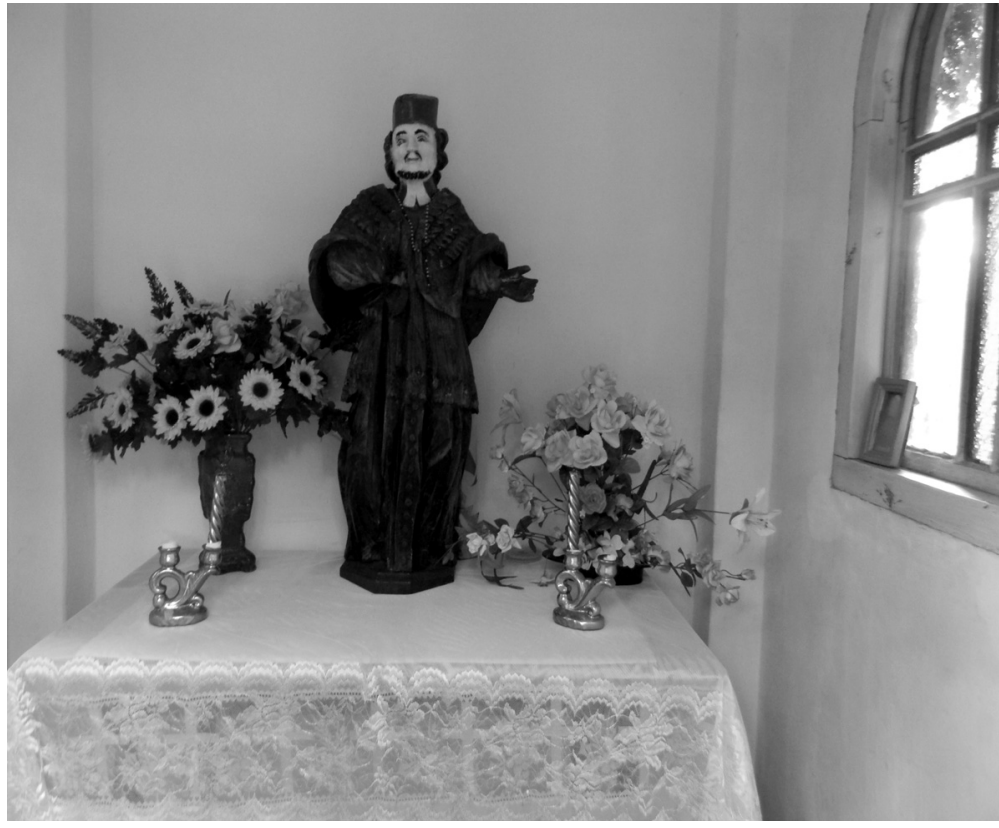

Fot. 6. Drewniana figura św. Jana Nepomucena w kapliczce w Liśniku Małym. Fot. Magdalena Lubiarz. 


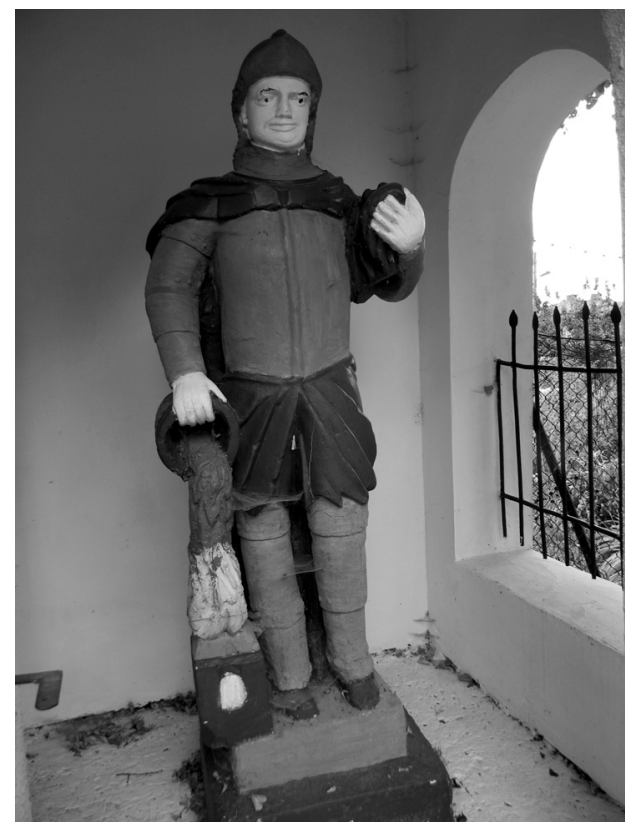

Fot. 7. Figura św. Floriana w kapliczce w Rzeczycy Ziemiańskiej. Fot. Magdalena Lubiarz.

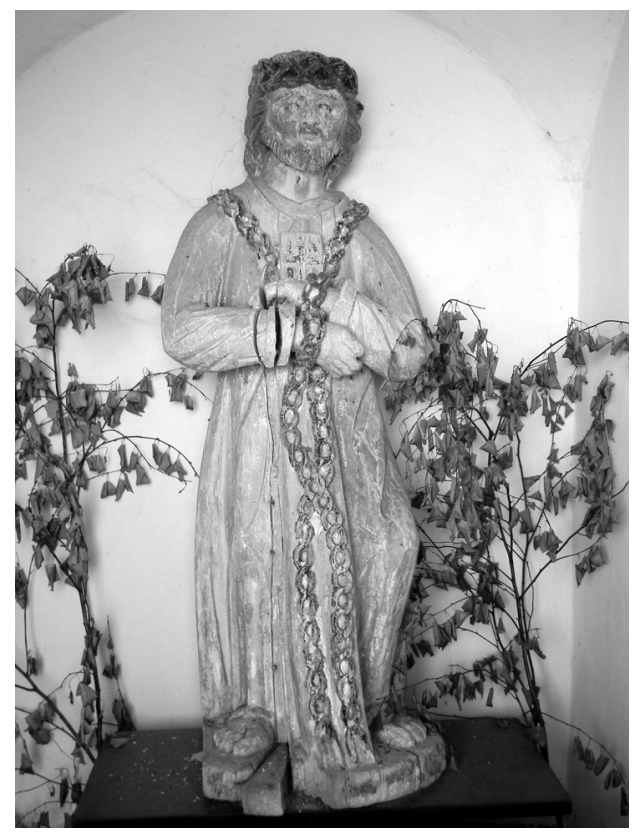

Fot. 8. Drewniana figura Chrystusa prowadzonego na Mękę w kapliczce w Owczarni. Fot. Małgorzata Żak-Kulesza. 


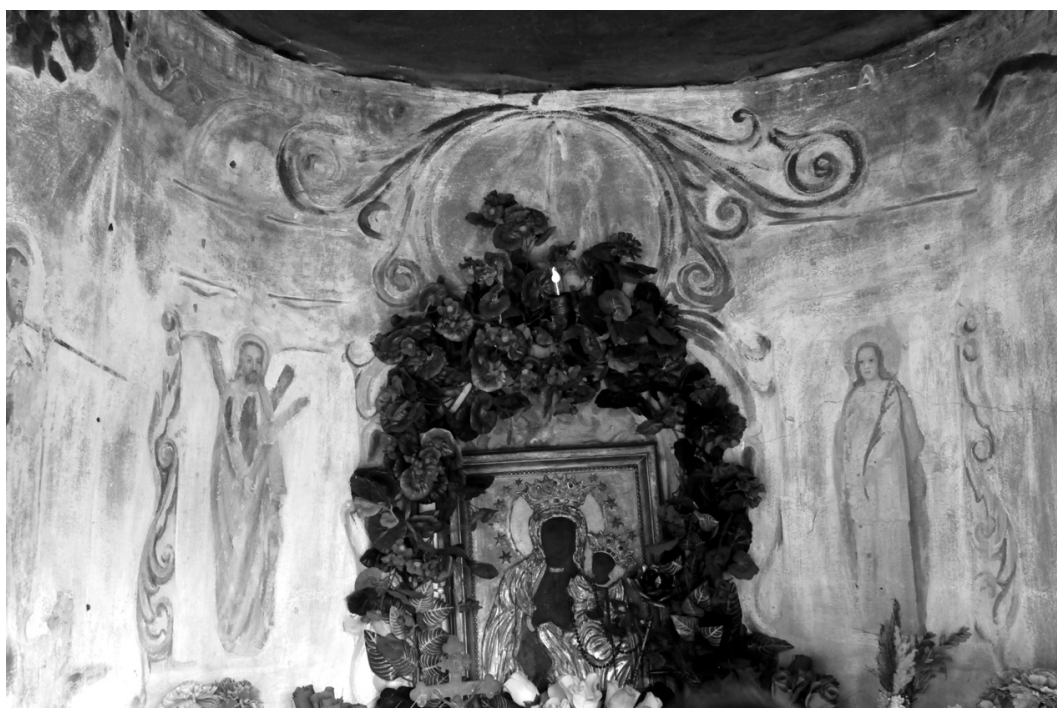

Fot. 9. Wnętrze kapliczki Matki Boskiej Częstochowskiej w kapliczce rodziny Wójcików w Łychowie Gościeradowskim, 1847 r. Fot. Magdalena Lubiarz.

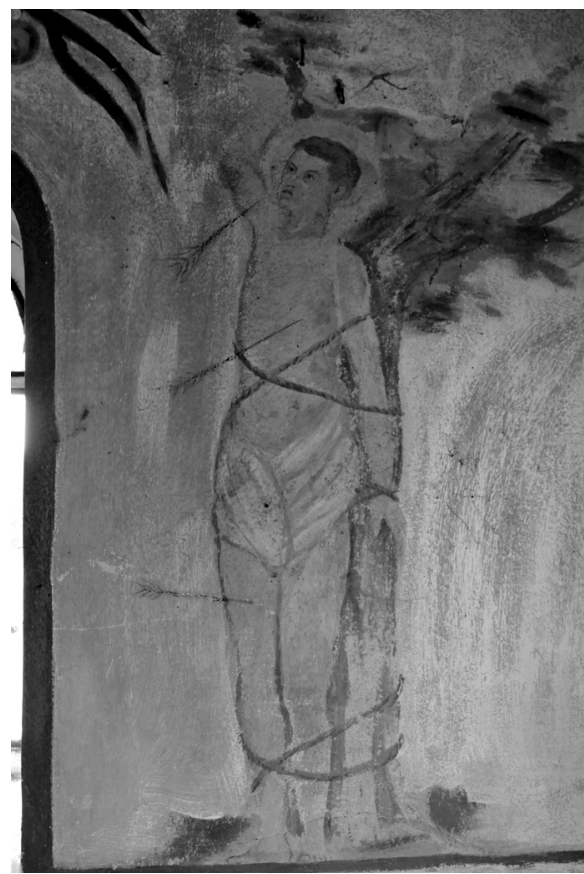

Fot. 10. Św. Sebastian, fragment polichromii w kapliczce w Łychowie Gościeradowskim, 1847 r. Fot. Magdalena Lubiarz. 


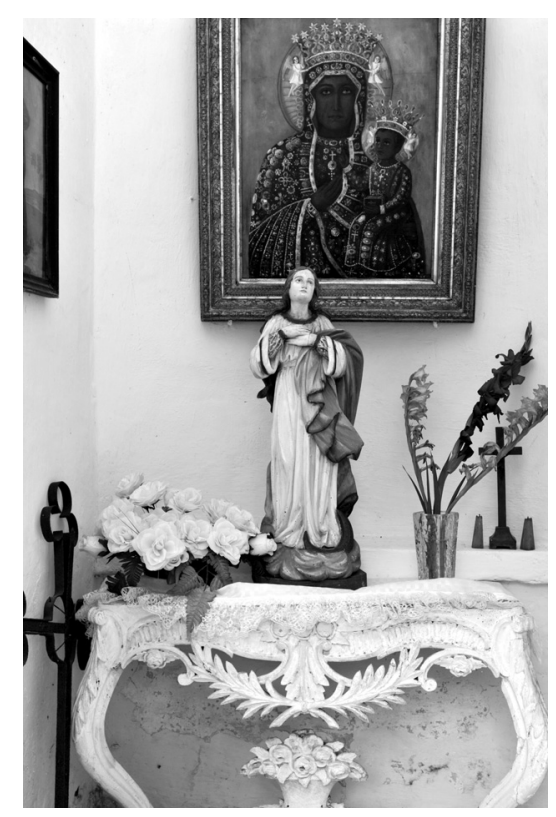

Fot. 11. Wnętrze kapliczki fundacji rodziny Gładkowskich w Rzeczycy Ziemiańskiej. Fot. Małgorzata Żak-Kulesza.

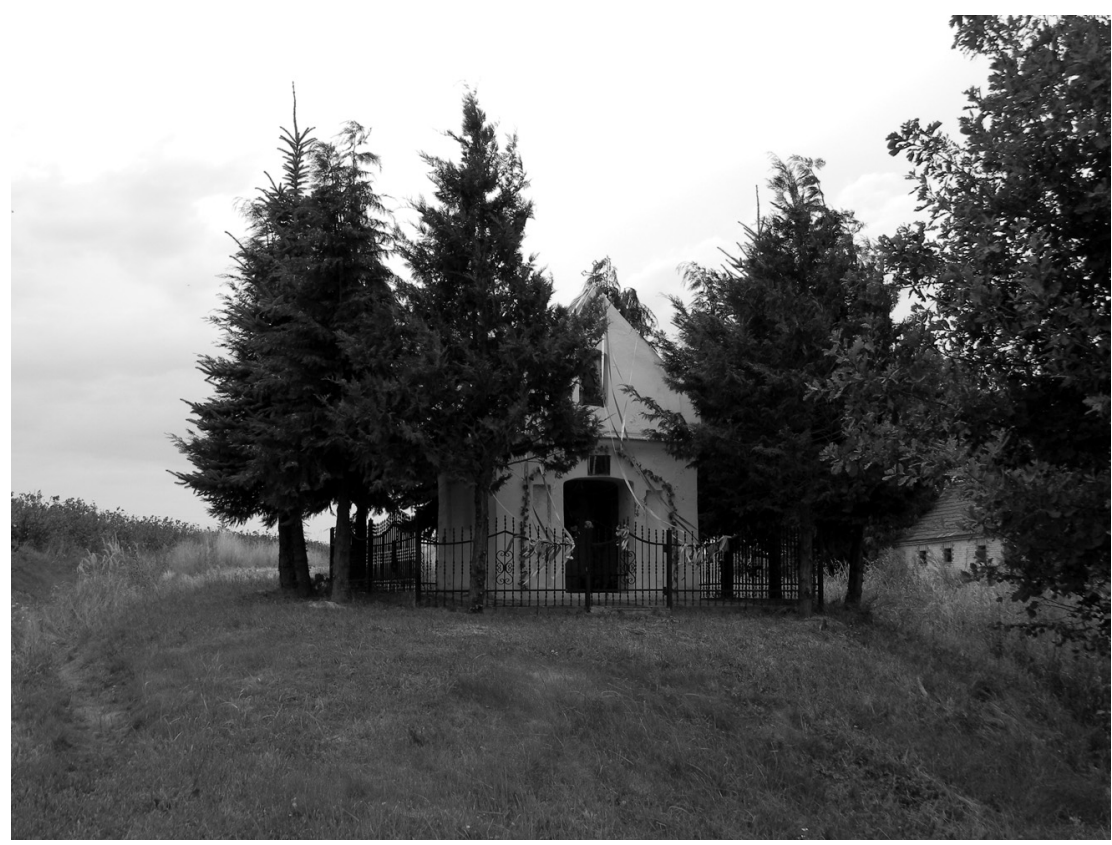

Fot. 12. Kapliczka fundacji rodziny Pytlaków w Łychowie Szlacheckim, 1856 r. Fot. Małgorzata Żak-Kulesza. 